\title{
Houttuynia cordata Thunb. and its bioactive compound 2-undecanone significantly suppress benzo(a)pyrene-induced lung tumorigenesis by activating the Nrf2-HO-1/ NQO-1 signaling pathway
}

Yanmei Lou ${ }^{1 \dagger}$, Zhenzhen Guo ${ }^{1 \dagger}$, Yuanfeng Zhu ${ }^{1+}$, Muyan Kong ${ }^{1}$, Rongrong Zhang ${ }^{1}$, Linlin Lu ${ }^{1,2}$, Feichi Wu ${ }^{3}$, Zhongqiu Liu ${ }^{1,2^{*}}$ and Jinjun $\mathrm{Wu}^{1 *}$

\begin{abstract}
Background: Lung cancer remains the most common cause of cancer-related deaths, with a high incidence and mortality in both sexes worldwide. Chemoprevention has been the most effective strategy for lung cancer prevention. Thus, exploring novel and effective candidate agents with low toxicity for chemoprevention is essential and urgent. Houttuynia cordata Thunb. (Saururaceae) (H. cordata), which is a widely used herbal medicine and is also popularly consumed as a healthy vegetable, exhibits anti-inflammatory, antioxidant and antitumor activity. However, the chemopreventive effect of $\mathrm{H}$. cordata against benzo(a)pyrene (B[a]P)-initiated lung tumorigenesis and the underlying mechanism remain unclear.
\end{abstract}

Methods: A B[a]P-stimulated lung adenocarcinoma animal model in A/J mice in vivo and a normal lung cell model (BEAS.2B) in vitro were established to investigate the chemopreventive effects of $\mathrm{H}$. cordata and its bioactive compound 2-undecanone against lung tumorigenesis and to clarify the underlying mechanisms.

Results: $\mathrm{H}$. cordata and 2-undecanone significantly suppressed B[a]P-induced lung tumorigenesis without causing obvious systemic toxicity in mice in vivo. Moreover, $\mathrm{H}$. cordata and 2-undecanone effectively decreased B[a]Pinduced intracellular reactive oxygen species (ROS) overproduction and further notably protected BEAS.2B cells from B[a]P-induced DNA damage and inflammation by significantly inhibiting phosphorylated H2A.X overexpression and interleukin-1 $\beta$ secretion. In addition, H. cordata and 2-undecanone markedly activated the Nrf2 pathway to induce the expression of the antioxidative enzymes heme oxygenase-1 ( $\mathrm{HO}-1)$ and $\mathrm{NAD}(\mathrm{P}) \mathrm{H}$ : quinone oxidoreductase 1 (NQO-1). Nrf2 silencing by transfection with Nrf2 siRNA markedly decreased the expression of HO-1 and NQO-1 to diminish the reductions in B[a]P-induced ROS overproduction, DNA damage and inflammation mediated by $\mathrm{H}$. cordata and 2-undecanone.

(Continued on next page)

\footnotetext{
*Correspondence: liuzq@gzucm.edu.cn; wujinjun@gzucm.edu.cn

†Yanmei Lou, Zhenzhen Guo and Yuanfeng Zhu contributed equally to this work.

'Joint Laboratory for Translational Cancer Research of Chinese Medicine of the Ministry of Education of the People's Republic of China, International Institute for Translational Chinese Medicine, Guangzhou University of Chinese Medicine, Guangzhou 510006, Guangdong, China

Full list of author information is available at the end of the article
}

(c) The Author(s). 2019 Open Access This article is distributed under the terms of the Creative Commons Attribution 4.0 International License (http://creativecommons.org/licenses/by/4.0/), which permits unrestricted use, distribution, and reproduction in any medium, provided you give appropriate credit to the original author(s) and the source, provide a link to the Creative Commons license, and indicate if changes were made. The Creative Commons Public Domain Dedication waiver (http://creativecommons.org/publicdomain/zero/1.0/) applies to the data made available in this article, unless otherwise stated. 


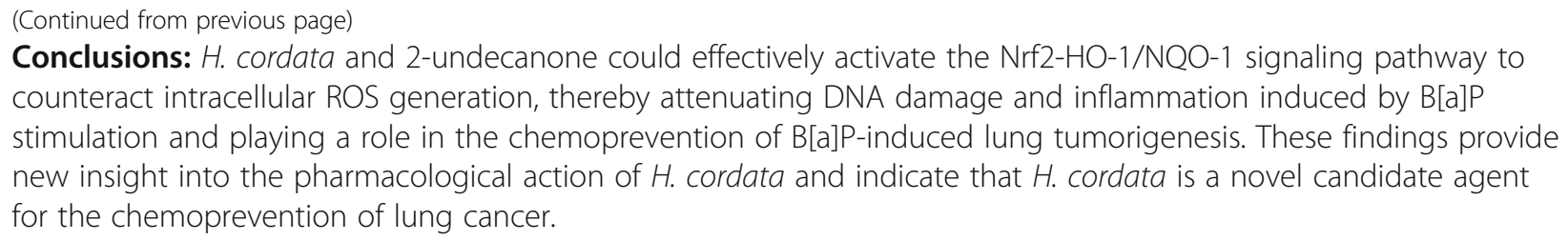

Keywords: Houttuynia cordata Thunb., 2-undecanone, benzo(a)pyrene, reactive oxygen species, DNA damage, inflammation, nuclear factor E2-related factor-2

\section{Background}

Worldwide, lung cancer remains the most frequently diagnosed cancer and the leading cause of cancer-related death, resulting in large social and economic burdens [1]. Many advanced treatments, including medical, surgical and radiotherapeutic interventions, have provided little effective improvement in the survival rates of patients diagnosed with primary lung malignancies [2]. The strong link between cigarette smoking and the development of lung cancer has been known for decades. The risk of lung cancer is 6 to 10 times higher in smokers than in nonsmokers [3], and almost $90 \%$ of patients diagnosed with lung cancer are cigarette smokers $[4,5]$. Although it is widely recognized that smoking prevention and cessation are the best approaches to prevent lung cancer, tobacco-related lung carcinogenesis is still prevalent because of the difficulty in controlling smoking [2]. According to the WHO guidelines, chemoprevention has been the most effective strategy for lung cancer prevention, especially for smokers with existing pulmonary premalignancies $[5,6]$. Therefore, it is essential and urgent to explore dietary factors that have the potential to prevent lung tumorigenesis.

Benzo(a)pyrene (B[a]P), which accounts for $22.5-69.8 \%$ of tobacco metabolites, can induce cell proliferation, inflammation, DNA alteration, and apoptosis, leading to lung cancer [7]. An evidenced-based study revealed that long-term exposure to $\mathrm{B}[\mathrm{a}] \mathrm{P}$ at a low dose could increase tumor incidence by up to $96.0 \%$ in animal models [8]. In part of its carcinogenic mechanism, $\mathrm{B}[\mathrm{a}] \mathrm{P}$ is metabolized into epoxide, which induces DNA adduct formation and causes mutations [9]. In addition, B[a]P-induced excessive production of reactive oxygen species (ROS), which results in oxidative stress, can lead to severe damage to DNA structure and is a prerequisite for $\mathrm{B}[\mathrm{a}] \mathrm{P}$-associated tumorigenesis [10-12]. Additionally, oxidative stressinduced inflammation is one of the major contributors to lung cancer initiation and progression [13, 14]. ROS in the respiratory system can increase the levels of pulmonary inflammation mediators and then initiate or promote lung carcinogenesis [15]. More importantly, there is a close relationship between ROS-induced DNA damage and inflammation, which can together accelerate the process of lung tumorigenesis. On the one hand, DNA damage may lead to chronic inflammation, which has been associated with the development of lung cancer [16-18]. On the other hand, under inflammatory conditions, ROS are generated in inflammatory and epithelial cells and further cause oxidative and nitrative DNA damage [19, 20]. Therefore, the use of appropriate preventive pharmacological interventions that can effectively reduce $\mathrm{B}[\mathrm{a}] \mathrm{P}$-induced DNA damage and inflammation has become an important strategy to prevent lung tumorigenesis.

Induction of enzymes that promote the detoxication of chemical carcinogens has been a broadly effective method for the chemoprevention of experimental carcinogenesis in rodent models [21]. The nuclear factorerythroid 2-related factor 2 (Nrf2) signaling pathway has been targeted for the prevention of chemical carcinogenesis.Nrf2 has been identified as a key regulator of the inducible expression of antioxidative enzymes, antiinflammatory proteins and conjugation/detoxification proteins, including $\mathrm{NAD}(\mathrm{P}) \mathrm{H}$ : quinone oxidoreductase 1 (NQO1) and heme oxygenase-1 (HO-1) [21]. Upon oxidative stress caused by $\mathrm{B}[\mathrm{a}] \mathrm{P}$ or pharmacologic induction, the Nrf2 pathway can be rapidly activated to counteract intracellular ROS generation, thereby attenuating DNA damage and inflammation promoted by $\mathrm{B}[\mathrm{a}] \mathrm{P}$ stimulation and contributing to reduced risk of mutation and subsequent lung tumorigenesis [21, 22]. Natural products are well known to exert their protective effects by removing free radicals, modulating the antioxidant defense system and performing carcinogen detoxification. To date, numerous compounds from natural plants have been found to activate Nrf2 signaling to effectively prevent $\mathrm{B}[\mathrm{a}] \mathrm{P}$-induced lung tumorigenesis. These Nrf2 stimulators include sulforaphane, green tea phenols, curcumin, quercetin, catechin, and naringenin [23-28]. Unfortunately, most of the antioxidants have failed phase III clinical trials for chemoprevention because of their poor bioavailability and reproducibility and/or harmful outcomes [29]. Thus, exploring more novel and effective candidate agents with low toxicity for chemoprevention is essential and urgent.

Houttuynia cordata Thunb. (Saururaceae) (H. cordata) is a well-known traditional Chinese medicinal herb 
widely used in China and Japan. Growing evidence suggests that $H$. cordata performs a variety of pharmacological functions, including antiviral, antitumor, antileukemia, anti-inflammatory, antioxidant, and antimutagenic functions [30,31]. Furthermore, $H$. cordata is also popularly consumed as a healthy vegetable in East Asia [32]. Chemically, $H$. cordata is composed of flavonoids, alkaloids, volatile oils, sterols, fatty acids, and polyphenolic acids [33, 34]. Among the components, 2undecanone is a vital bioactive compound that exhibits various types of biological activity $[35,36]$ and is used as a standard marker for quality control of $H$. cordata in the Chinese Pharmacopoeia. According to modern pharmacological studies and clinical practices, H. cordata is especially suitable for the treatment of lung diseases. For example, during an outbreak of severe acute respiratory syndrome, $H$. cordata was proposed to be an effective alternative treatment [30]. H. cordata also exerts a protective effect against bleomycin-induced pulmonary fibrosis [30] and may alleviate lipopolysaccharide-induced lung inflammatory injury [37]. It has also been demonstrated that $H$. cordata exhibits anti-lung cancer activity [38]. However, the chemopreventive effect of $H$. cordata against $\mathrm{B}$ [a]P-induced lung carcinogenesis and the underlying mechanism have not yet been explored.

In the current study, a B[a]P-stimulated lung adenocarcinoma animal model in A/J mice in vivo and a normal lung cell (BEAS.2B) model in vitro were established to investigate the chemopreventive effects of $H$. cordata and 2-undecanone against $\mathrm{B}[\mathrm{a}] \mathrm{P}$-induced lung tumorigenesis. We also clarified the underlying mechanisms by which $H$. cordata and 2-undecanone could prevent lung carcinogenesis by measuring molecular markers of oxidative DNA damage and inflammation mediated by the Nrf2-HO-1/NQO-1 signaling pathway. The results of this study will enhance understanding of the chemopreventive effects of $H$. cordata against $\mathrm{B}$ [a]P-stimulated lung tumorigenesis and the underlying mechanisms, thereby supporting the use of this novel candidate agent for the chemoprevention of lung cancer.

\section{Materials and methods}

\section{Chemicals and reagents}

A dried Houttuyniae Herba, the aerial part of H. cordata, was purchased from Hunan Zhengqing Pharmaceutical Co., Ltd. (Hunan, China), and was authenticated by Guangzhou University of Chinese Medicine as the aerial part of Houttuynia cordata Thunb. (Saururaceae). A voucher specimen was deposited in Guangzhou University of Chinese Medicine. 2-Undecanone (purity > 99\%), benzo(a)pyrene (B[a]P, purity $>98 \%)$, tert-Butylhydroquinone (tBHQ), N-Acetyl-L-cysteine (NAC), and 3-(4, 5dimethylthiazol-2-yl)-2, 5-diphenyltetrazolium bromide
(MTT) were bought from Sigma-Aldrich (St. Louis, MO, USA). Primary antibodies NQO-1, HO-1 and Nrf2 were purchased from Abcam Inc. (Cambridge, MA, USA). Primary antibodies phosphorylated H2A.X (p-H2A.X) and Cyclin D1 were purchased from Cell Signaling Technology Inc. (Boston, USA). Primary antibodies interleukin-1 $\beta$ (IL-1 $\beta$ ) and pro-IL-1 $\beta$ were purchased from R\&D Systems Inc. (Minneapolis, Minnesota, USA). 5-Ethynyl-2'-deoxyuridine (EdU) kit, Nrf2-specific siRNA (siNrf2), control siRNA (siCtrl) and riboFECTTM CP Transfection kit were purchased from RiboBio Co., Ltd. (Guangzhou, China). Cellular ROS Detection Reagent (CM-H2DCFDA) was purchased from Invitrogen (Thermo Fisher Scientific Inc., Waltham, MA, US). Mouse IL- $1 \beta$ ELISA Kit was purchased from MultiSciences(Lianke)Biotech Co., Ltd. (Hangzhou, China). Anti-Rabbit HRP-DAB Cell \& Tissue Staining Kit was purchased from R\&D Systems Inc. (Minneapolis, Minnesota, USA). NE-PER nuclear and cytoplasmic extraction reagents were purchased from Pierce Biotechnology Inc. (Rockford, IL, USA). All other chemicals and solvents were of analytical grade or better and used as received.

\section{Preparation of H.cordata water extract and standardization}

$H$. cordata was cut into pieces approximately $1 \mathrm{~cm}$ long. A total of $100 \mathrm{~g}$ of $\mathrm{H}$. cordata was subjected to hydrodistillation for $4 \mathrm{~h}$ in a Clevenger apparatus following the procedure described in the Chinese Pharmacopoeia. The supernatant essential oils were isolated. The lower aqueous solution was filtered out with gauze. Next, the dregs were re-extracted under the same conditions. Afterward, the two successively obtained aqueous solutions were merged and condensed by a rotatory evaporator (EYELA, Rikakikai Co., Ltd., Tokyo, Japan) under reduced pressure. After cooling, the condensed filtrates and the two isolated supernatant essential oil samples were merged. The final concentration of the $H$. cordata water extract was $1 \mathrm{~g} / \mathrm{mL}$, and it was stored at $-20{ }^{\circ} \mathrm{C}$ for later use.

Chemical profiling and standardization of H.cordata water extract using 2-undecanone was performed by using gas chromatography with flame ionization detection (GC-FID) with an external standard method (Additional materials and methods and Additional file 1: Figure S1). 2-Undecanone was measured in H.cordata water extract at mean levels of $0.099 \pm 0.011 \mathrm{mg} / \mathrm{g}$.

\section{Cell culture}

BEAS-2B cells were obtained from ATCC (Manassas, Virginia, USA). The cells cultured in Bronchial Epithelial Cell Basal Medium (BEGM) medium supplemented with $0.4 \%(\mathrm{v} / \mathrm{v})$ bovine pituitary extraction (BPE), $0.1 \%(\mathrm{v} / \mathrm{v})$ hydrocortisone, $0.1 \%(\mathrm{v} / \mathrm{v})$ human epidermal growth 
factor (hEGF), 0.1\% (v/v) epinephrine, $0.1 \%(\mathrm{v} / \mathrm{v})$ insulin, $0.1 \%(\mathrm{v} / \mathrm{v})$ transferrin, $0.1 \%(\mathrm{v} / \mathrm{v})$ triiodothyronine, $0.1 \%$ $(\mathrm{v} / \mathrm{v})$ retinoic acid, and $0.1 \% \quad(\mathrm{v} / \mathrm{v})$ gentamicin amphotericin-B (GA). The cells were grown at $37{ }^{\circ} \mathrm{C}$ in a humidified atmosphere with $5 \% \mathrm{CO}_{2}$.

\section{Animals and treatments}

Male A/J mice (4-6 weeks old, 18-22 g) were supplied by the Jackson Laboratory Animal Center (No.99612800000100) (Maine, USA). All mice were kept in the animal facility in a specific pathogen-free (SPF) animal laboratory (license number: SYXK (GZ) 2014-0144) at the International Institute for Translational Chinese Medicine, Guangzhou University of Chinese Medicine (Guangzhou, China). The mice were intraperitoneally injected with $\mathrm{B}[\mathrm{a}] \mathrm{P}(100 \mathrm{mg} / \mathrm{kg})$. After two weeks, all mice were randomly divided into 6 groups $(8$ mice per group), as follows: a control group treated with $\mathrm{B}[\mathrm{a}] \mathrm{P}$ in a water vehicle, groups treated with 25 and $50 \mathrm{~g} / \mathrm{kg} \mathrm{H}$. cordata, a control group treated with $\mathrm{B}[\mathrm{a}] \mathrm{P}$ in a sterilized corn oil vehicle, and groups treated with 100 and $200 \mathrm{mg} / \mathrm{kg} \mathrm{2-}$ undecanone. The mice were orally treated with the drugs five times a week for 38 weeks. The body weights were recorded every week. At the end of the treatment, the mice were sacrificed, and the organs were removed and weighed. The organ indexes (organ weight/body weight) were statistically analyzed. Mouse lung images were captured by using an M165C stereoscopic microscope (Leica Microsystems, Wetzlar, Germany). The lungs and plasma of the mice were collected for subsequent assays. Animal experiments were approved by the Guangzhou University of Chinese Medicine Animal Care and Use Committee (Guangzhou, China), and conducted in accordance with the ethical standards and national guidelines.

\section{MTT assay}

BEAS-2B cells were seeded in 96-well plates for $24 \mathrm{~h}$ before the addition of drugs. The cells were exposed to vehicle (water), B[a]P $(0-50 \mu \mathrm{M})$ alone, H.cordata (0-200 $\mathrm{mg} / \mathrm{mL})$ alone, $\mathrm{B}[\mathrm{a}] \mathrm{p}(5 \mu \mathrm{M})$ plus H.cordata $(0-100 \mathrm{mg} /$ $\mathrm{mL}), 2$-undecanone $(0-200 \mu \mathrm{M})$ alone, or $\mathrm{B}[\mathrm{a}] \mathrm{p}(5 \mu \mathrm{M})$ plus 2-undecanone $(0-200 \mu \mathrm{M})$ for $48 \mathrm{~h}$. At the end of the incubation, $100 \mu \mathrm{L}$ of MTT solution $(0.5 \mathrm{mg} / \mathrm{mL}$ in PBS) was added to each well, and the cells were incubated at $37{ }^{\circ} \mathrm{C}$ for an additional $4 \mathrm{~h}$. Then, the medium was removed, the intracellular formazan was solubilized with $150 \mu \mathrm{L}$ of DMSO, and the absorbance was read at $570 \mathrm{~nm}$ using a Victor X3 microplate reader (PerkinElmer, Waltham, MA, USA). The percentage of cell viability was calculated based on the measured absorbance relative to the absorbance of the control cells.

\section{5-Ethynyl-2'-deoxyuridine (EdU) assay}

EdU was used to detect cell proliferation ability. BEAS2B cells were seeded into 96-well plates and exposed to vehicle (water), $\mathrm{B}[\mathrm{a}] \mathrm{P}(5 \mu \mathrm{M})$ alone, $\mathrm{B}[\mathrm{a}] \mathrm{P}(5 \mu \mathrm{M})$ plus H.cordata $(12.5,25$, or $50 \mathrm{mg} / \mathrm{mL})$, or $\mathrm{B}[\mathrm{a}] \mathrm{P}(5 \mu \mathrm{M})$ plus 2-undecanone $(25,50$, or $100 \mu \mathrm{M})$ for $48 \mathrm{~h}$. After incubation, the cells were incubated with EdU labeling medium $(10 \mu \mathrm{M})$ for $24 \mathrm{~h}$, fixed with $4 \%$ paraformaldehyde for $30 \mathrm{~min}$, and incubated with glycine $(2 \mathrm{mg} / \mathrm{ml})$ for $5 \mathrm{~min}$. Then, the cells were incubated with $1 \times$ Apollo 488 working solution for $30 \mathrm{~min}$, washed with PBS, and stained with Hoechst 33342 dye for 30 min. Images were captured by using a Leica3000B fluorescence microscope (Leica, Germany). The percentages of EdU-positive cells were calculated from 6 random fields.

\section{Cell cycle assay}

BEAS-2B cells were seeded in 6-well plates and exposed to the vehicle (water), $\mathrm{B}[\mathrm{a}] \mathrm{P}(5 \mu \mathrm{M})$ alone, $\mathrm{B}[\mathrm{a}] \mathrm{P}(5 \mu \mathrm{M})$ plus H.cordata $(12.5,25,50 \mathrm{mg} / \mathrm{mL})$, or $\mathrm{B}[\mathrm{a}] \mathrm{P}(5 \mu \mathrm{M})$ plus 2-undecanone $(25,50,100 \mu \mathrm{M})$ for $48 \mathrm{~h}$, respectively. After the incubation, the cells were harvested, fixed with $70 \%$ cold ethanol at $4{ }^{\circ} \mathrm{C}$ overnight, and stained with propidium iodide $(5 \mu \mathrm{g} / \mathrm{mL})$ for $30 \mathrm{~min}$. Cell cycle was detected by a flow cytometry (BD Biosciences, San Jose, CA) and were analyzed by FlowJo 7.6 software.

\section{Protein preparation and Western blot analysis}

At the end of treatment, the total proteins in the treated cells and the lung of mice were extracted using the RIPA buffer containing a protease inhibitor cocktail. The nuclear protein extracts of the cells were also prepared using NE-PER nuclear and cytoplasmic extraction reagents (Rockford, IL, USA) according to the manufacturer's instructions. The proteins in the cell-free supernatants were prepared as previously published procedure [39]. Protein concentrations were determined with a BCA estimation kit according to the manufacturer's instructions. Western blotting was performed as previously described [40].

\section{Comet assay}

A comet assay was used to detect DNA strand breaks at the single-cell level. BEAS-2B cells were seeded in 6-well plates and exposed to vehicle (water), B[a]P $(5 \mu \mathrm{M})$ alone, $\mathrm{B}[\mathrm{a}] \mathrm{P}(5 \mu \mathrm{M})$ plus H.cordata $(12.5,25$, or $50 \mathrm{mg} /$ $\mathrm{mL})$, or $\mathrm{B}[\mathrm{a}] \mathrm{P}(5 \mu \mathrm{M})$ plus 2 -undecanone $(25,50$, or 100 $\mu \mathrm{M})$ for $48 \mathrm{~h}$. After incubation, the cells were harvested and suspended in low-melting point agarose. After the cells were spread on normal-melting point agarosecoated slides, the slides were covered with a coverslip and left at $4{ }^{\circ} \mathrm{C}$. After removing the coverslips, the slides were then immersed in cell lysis solution for 60 minutes at $4{ }^{\circ} \mathrm{C}$. Then, the slides were transferred to an electrophoretic box and left for 60 minutes at $4^{\circ} \mathrm{C}$. Electrophoresis was performed at $4{ }^{\circ} \mathrm{C}$ for 25 minutes. The slides 
were then washed and immersed in ethanol for another 20 minutes. Finally, the slides were stained with EB solution $(20 \mu \mathrm{g} / \mathrm{mL})$ and covered with coverslips. Images were captured by using a Leica3000B fluorescence microscope (Leica, Germany).

\section{Immunofluorescence}

BEAS-2B cells were seeded on confocal dishes and exposed to the vehicle (water), $\mathrm{B}[\mathrm{a}] \mathrm{P}(5 \mu \mathrm{M})$ alone, $\mathrm{B}[\mathrm{a}] \mathrm{P}$ $(5 \mu \mathrm{M})$ plus H.cordata $(12.5,25$, or $50 \mathrm{mg} / \mathrm{mL})$, or B[a]P $(5 \mu \mathrm{M})$ plus 2-undecanone $(25,50$, or $100 \mu \mathrm{M})$ for $48 \mathrm{~h}$, respectively. After the incubation, the cells were fixed in cold methanol, permeabilized with $0.1 \%$ TritonX-100 and blocked with $5 \%$ bovine serum albumin. Then, the cells were incubated with a p-H2A.X (1:100) or a Nrf2 $(1: 100)$ antibody for $1 \mathrm{~h}$ and then stained with a secondary fluorescent antibody (1:200; Alexa Fluor 568, Abcam Inc. Cambridge, MA, USA). Finally, the cells were incubated with DAPI for another $20 \mathrm{~min}$. Fluorescence signals were detected using a Leica TCS SP8 confocal fluorescence microscope (Leica, Germany). The relative fluorescence of p-H2A.X in the cells was analysed by ImageJ software.

\section{Intracellular ROS measurement}

BEAS-2B cells were seeded in six-well plates and exposed to vehicle (water), $\mathrm{B}[\mathrm{a}] \mathrm{P}(5 \mu \mathrm{M})$ alone, $\mathrm{B}[\mathrm{a}] \mathrm{P}(5 \mu \mathrm{M})$ plus H.cordata $(12.5,25$, or $50 \mathrm{mg} / \mathrm{mL})$, or $\mathrm{B}[\mathrm{a}] \mathrm{P}(5 \mu \mathrm{M})$ plus 2-undecanone $(25,50$, or $100 \mu \mathrm{M})$ for $48 \mathrm{~h}$. N-Acetyl-Lcysteine (NAC, $2 \mathrm{mM}$ ), a well-known ROS inhibitor, was used as a positive control. After incubation, the cells were washed twice with PBS and incubated with a ROS detection reagent (CM-H2DCFDA, $5 \mu \mathrm{M}$ ) for $30 \mathrm{~min}$ at $37^{\circ} \mathrm{C}$. The fluorescence signals were detected by using flow cytometry (BD Biosciences, San Diego, CA, USA) or a Leica3000B fluorescence microscope (Leica, Germany). The results were analyzed with Flowjo 7.6 software.

\section{siRNA interference}

siRNA interference was performed using a riboFECT ${ }^{\mathrm{TM}}$ CP Transfection Kit (RiboBio Co., Ltd., Guangzhou, China) according to the manufacturer's instructions. Briefly, siRNA was diluted in transfection buffer and then mixed with riboFECT ${ }^{\mathrm{TM}} \mathrm{CP}$. The mixture was incubated at room temperature for 0-10 minutes to form a transfection complex. The complex was added to a suitable amount of cell culture medium for transfection. Finally, the cells were transfected with $50 \mathrm{nM}$ Nrf2targeting siRNA (siNrf2) or control siRNA (siCon). After a $24 \mathrm{~h}$ transfection, the cells were exposed to the same treatment described above. At the end of treatment, the cells were collected for Western blot analysis, ROS content measurement or MTT assay under the same conditions described above.

\section{Immunohistochemistry}

At the end of treatment, the lung tissues of the mice were removed, fixed in paraformaldehyde, embedded in paraffin, and sliced into $4 \mu \mathrm{m}$ sections. Then, the slices were deparaffinized, rehydrated and incubated with sodium citrate for antigen retrieval. Next, the slides were rinsed in $\mathrm{PBS}$ and incubated with antibodies against $\mathrm{p}$ H2A.X, NQO-1, HO-1 or Nrf2 at $4{ }^{\circ} \mathrm{C}$ overnight. The following steps were performed using an immunostaining kit (Boster Biological Technology Co., Ltd.) according to the manufacturer's instructions. All sections were imaged under a microscope (Leica, Germany).

\section{Enzyme-linked immunosorbent assay (ELISA)}

At the end of treatment, the plasma of the mice was collected. The levels of IL-1 $\beta$ were detected by a mouse IL$1 \beta$ ELISA kit according to the manufacturer's protocol. The optical density was measured at $450 \mathrm{~nm}$ by using a microplate reader Victor X3 (PerkinElmer, Waltham, MA, USA).

\section{Hematoxylin and Eosin (H\&E) Staining}

At the end of treatment, lung tissues of the mice were removed and fixed in $4 \%$ paraformaldehyde, then embedded in paraffin and sliced into $4 \mu \mathrm{m}$. Following, The slices were dewaxed and rehydrated, then stained by hematoxylin for $2 \mathrm{~min}$ and $1 \%$ ethyl hydrochloride for 5 s. Finally, the cytoplasm was stained by eosin for $2 \mathrm{~min}$. The images were acquired by using a fluorescence inversion microscope (Leica, Germany).

\section{Data analysis}

The data are expressed as the mean \pm standard deviation (SD). The statistical significance of data was analyzed using Student's $t$-test or one-way analysis of variance (ANOVA) by SPSS 19.0. Values of $p<0.05$ was considered to be statistically significant.

\section{Results}

H. cordata and 2-undecanone prevent lung tumorigenesis in $\mathrm{B}$ [a]P-induced lung cancer mouse model

A B[a]P-induced lung cancer mouse model was established to evaluate the chemopreventive effects of $H$. cordata and 2-undecanone against lung tumorigenesis. As shown in Fig. 1a, A/J mice were intraperitoneally injected with $\mathrm{B}[\mathrm{a}] \mathrm{P}(100 \mathrm{mg} / \mathrm{kg})$ at the $1 \mathrm{st}$ week. From the 3rd to 38th weeks, H.cordata ( 25 or $50 \mathrm{~g} /$ $\mathrm{kg}$ ) or 2-undecanone (100 or $200 \mathrm{mg} / \mathrm{kg}$ ) was administered by gavage five times a week. There were no significant body weight differences between the control group $\mathrm{A} / \mathrm{J}$ mice (given only $\mathrm{B}[\mathrm{a}] \mathrm{P}$ ) and the treatment group A/J mice during the experiment (Fig. 1b). Stereological observations and H\&E staining of the pathological sections showed that the lung tissue was 




cancerous after the model was established, but the symptoms were relieved after treatment with $H$. cordata and 2-undecanone (Additional file 1: Figure S2). The results regarding visible tumors on the lung surface among the groups are shown in Fig. 1c. In contrast to the control mice (given $\mathrm{B}[\mathrm{a}] \mathrm{P}$ ), which exhibited abundant tumor loci, the mice receiving $\mathrm{B}[\mathrm{a}] \mathrm{P}$ and $H$. cordata at 25 and $50 \mathrm{~g} / \mathrm{kg}$ exhibited significantly ( $p<0.05$ and $p<0.01$, respectively) decreased mean tumor numbers, and the corresponding tumor inhibition rates were $34.12 \pm 21.42 \%(p<0.05)$ and $51.35 \pm 21.96 \%(p<0.01)$, respectively (Fig. 1c). In contrast to the control mice (given $\mathrm{B}[\mathrm{a}] \mathrm{P}$ and oil) showing abundant tumor loci, the mice receiving $\mathrm{B}[\mathrm{a}] \mathrm{P}$ with 2-undecanone at 100 and $200 \mathrm{mg} / \mathrm{kg}$ also exhibited significantly $(p<0.05$ and $p<0.01$, respectively) decreased mean tumor numbers, and the corresponding tumor inhibition rates were $33.62 \pm 14.60 \%$ $(p<0.05)$ and $38.26 \pm 13.59 \%(p<0.01)$, respectively (Fig. 1c). The organ indexes are displayed in Fig. 1d; no considerable differences were observed in the indexes for the heart, kidney, thymus, liver and spleen between the model group and the treatment groups.
H. cordata and 2-undecanone protect BEAS-2B cells from $\mathrm{B}[\mathrm{a}] \mathrm{P}$-induced cytotoxicity, proliferation inhibition and cell cycle arrest

The cytotoxicity of $H$. cordata and 2-undecanone toward BEAS-2B cells was evaluated by using an MTT assay. Compared with vehicle (water) treatment, treatment with $\mathrm{B}[\mathrm{a}] \mathrm{P}$ resulted in a significant decrease in the viability of BEAS-2B cells in a dose-dependent manner (Additional file 1: Figure S3, $p<0.05$ or $p<0.001$ ). Incubation of cells with $H$. cordata at concentrations from 6.25 to $200 \mathrm{mg} / \mathrm{L}$ or with 2-undecanone at concentrations from 6.25 to $200 \mu \mathrm{M}$ for $48 \mathrm{~h}$ did not change or weakly decreased cell viability (Fig. 2a and b). However, in contrast to $\mathrm{B}[\mathrm{a}] \mathrm{P}(5 \mu \mathrm{M})$ treatment alone (in the model group), cotreatment with $\mathrm{B}[\mathrm{a}] \mathrm{P}$ and H.cordata (3.125-100 $\mathrm{mg} / \mathrm{mL})$ or 2-undecanone $(6.25-200 \mu \mathrm{M})$ effectively increased cell viability in a dose-dependent manner (Fig. 2c and d, $p<0.05$ or $p<0.001$ ).

Furthermore, EdU assays and cell cycle assays were performed to analyze the protective effects of $H$. cordata and 2-undecanone against $\mathrm{B}[\mathrm{a}] \mathrm{P}$-induced cell proliferation inhibition. In contrast to the control cells (given water), which showed a relative abundance of EdU- 


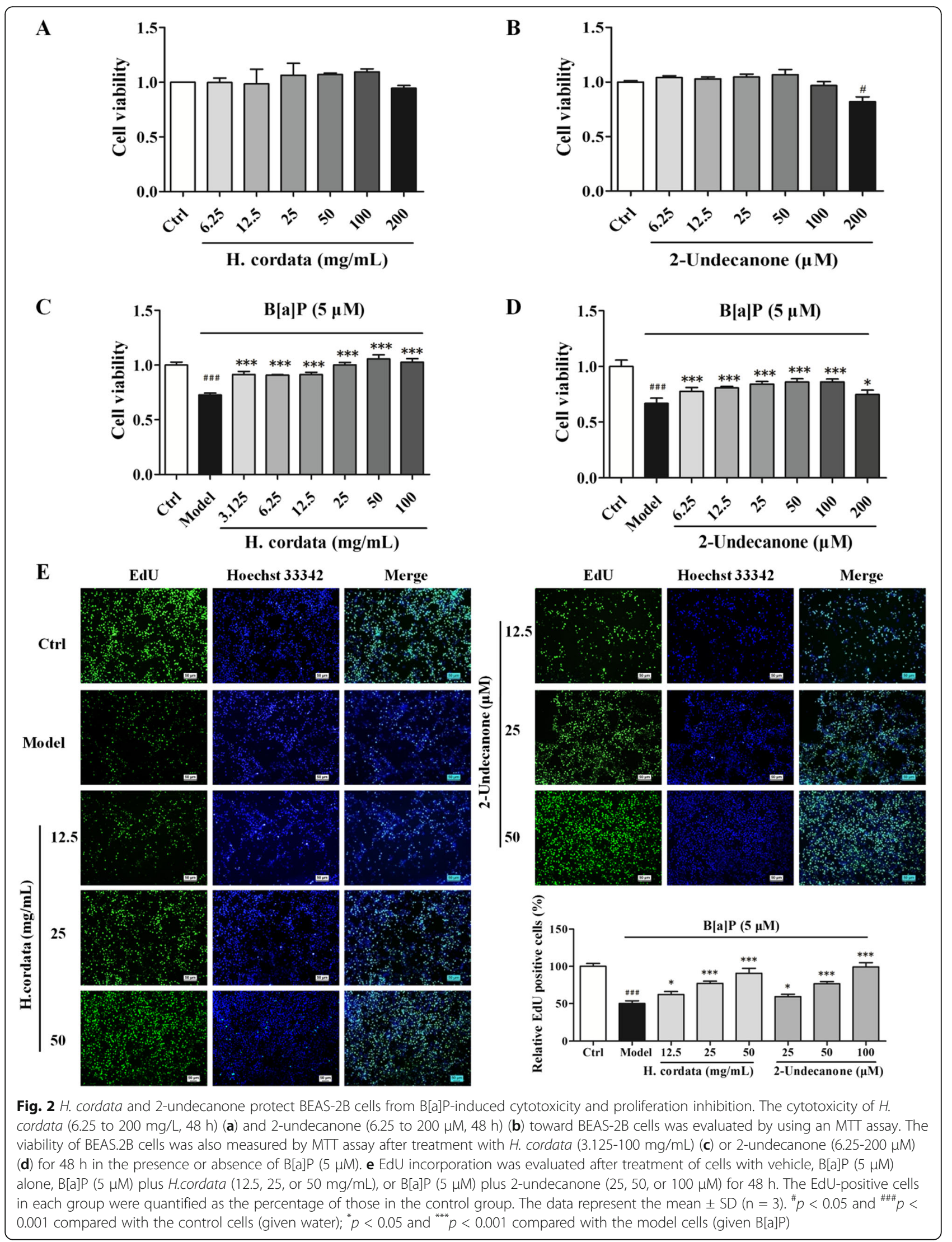


positive cells, B[a]P $(5 \mu \mathrm{M})$-treated cells showed significantly suppressed cell proliferation rates (Fig. 2e, $p<$ 0.001). However, compared with incubation with $\mathrm{B}[\mathrm{a}] \mathrm{P}$ alone (in the model group), incubation of cells with $\mathrm{B}[\mathrm{a}] \mathrm{P}$ plus $H$. cordata $(12.5,25$ or $50 \mathrm{~g} / \mathrm{kg})$ or 2-undecanone $(25$, 50 or $100 \mu \mathrm{M})$ for $48 \mathrm{~h}$ markedly increased the proliferation rate in a dose-dependent manner (Fig. 2e, $p<0.05$ or $p<0.001)$. In addition, $\mathrm{B}[\mathrm{a}] \mathrm{P}(5 \mu \mathrm{M})$ notably arrested the cell cycle at the G0/G1 phase by increasing the percentage of cells in this phase from $46.05 \pm 2.75 \%$ (the control level) to $70.21 \pm 1.65 \%$ (Fig. $3 \mathrm{a}, p<0.01$ ). However, cotreatment with $\mathrm{B}[\mathrm{a}] \mathrm{P}$ and $H$. cordata or 2-undecanone significantly decreased the percentage of cells arrested in G0/G1 phase in a dose-dependent manner compared with $\mathrm{B}[\mathrm{a}] \mathrm{P}$ treatment alone (in model cells) (Fig. 3a, $p<0.01$ or $p<0.001$ ). The levels of cyclin D1, a vital regulator required for G1 phase progression, were further determined by using Western blot analysis. It was observed that the suppression of cyclin $\mathrm{D} 1$ protein levels by $\mathrm{B}[\mathrm{a}] \mathrm{P}$ could be significantly reversed by $H$. cordata (Fig. $3 \mathrm{~b}, p<0.001$ ) or 2 undecanone (Fig. 3c, $p<0.05$ or $p<0.01$ ) treatment.

\section{$H$. cordata and 2-undecanone protect BEAS-2B cells and $A / J$ mice from $B[a] P$-induced DNA damage}

A comet assay was performed to detect the DNA damage rates in treated BEAS-2B cells. As shown in Fig. 4a, in contrast to the control cells (given water), cells treated with $\mathrm{B}[\mathrm{a}] \mathrm{P}(5 \mu \mathrm{M})$ for $48 \mathrm{~h}$ exhibited notably enhanced fluorescence in migrated DNA and extended tails of disrupted DNA fragments, suggesting that $\mathrm{B}[\mathrm{a}] \mathrm{P}$ could cause DNA damage in BEAS-2B cells. In contrast, compared with the $\mathrm{B}[\mathrm{a}] \mathrm{P}$ model group, the groups incubated with $\mathrm{B}[\mathrm{a}] \mathrm{P}$ plus $\mathrm{H}$. cordata $(12.5,25$ or $50 \mathrm{~g} / \mathrm{kg}$ ) or 2-undecanone $(25,50$ or $100 \mu \mathrm{M})$ for 48 h exhibited attenuated $\mathrm{B}[\mathrm{a}] \mathrm{P}$-induced DNA damage, as demonstrated by decreased fluorescence and reduced migrated tails of damaged DNA.

DNA double-strand breaks induce histone H2A.X phosphorylation, which is associated with the recruitment of repair factors to damaged DNA. Thus, p-H2A.X has been used as a marker for DNA damage [41-43]. Hence, the protein levels of p-H2A.X in BEAS-2B cells and $A / J$ mouse lung tissue were further determined by Western blot analysis. As shown in Fig. 4b, compared with control cells (given water), cells treated with $\mathrm{B}[\mathrm{a}] \mathrm{P}$ showed markedly increased p-H2A.X protein levels $(p<$ 0.001). In contrast to $\mathrm{B}[\mathrm{a}] \mathrm{P}$ exposure alone (in the model group), exposure to $\mathrm{B}[\mathrm{a}] \mathrm{P}$ plus $12.5,25$ or $50 \mathrm{~g} / \mathrm{kg} H$. cordata significantly decreased the p-H2A.X protein levels in a dose-dependent manner $(p<0.001)$. Similar results were also observed after incubation with $\mathrm{B}[\mathrm{a}] \mathrm{P}$ plus 25, 50 or $100 \mu \mathrm{M}$ 2-undecanone, which significantly decreased the $\mathrm{B}[\mathrm{a}] \mathrm{P}$-induced high expression of $\mathrm{p}$ H2A.X in a dose-dependent manner (Fig. 4c, $p<0.001$ ).
An immunofluorescence assay was further performed to confirm the protective effects of $H$. cordata and 2undecanone against $\mathrm{B}[\mathrm{a}] \mathrm{P}$-induced DNA damage. As shown in Fig. 4d, the immunofluorescence of p-H2A.X in the $H$. cordata and 2-undecanone treatment groups was strikingly lower than that in the $\mathrm{B}[\mathrm{a}] \mathrm{P}$ model group $(p<0.001)$, which was consistent with the $\mathrm{p}-\mathrm{H} 2 \mathrm{~A} . \mathrm{X}$ protein levels obtained from the Western blot analysis (Fig. $4 \mathrm{~b}$ and c). The p-H2A.X protein levels in the lung tissues of mice were also determined. Both $H$. cordata and 2-undecanone treatment significantly downregulated $\mathrm{p}$ H2A.X expression compared with $\mathrm{B}[\mathrm{a}] \mathrm{P}$ alone (Fig. 4e and $\mathrm{f}, p<0.01$ or $p<0.001$ ).

\section{H. cordata and 2-undecanone protect BEAS-2B cells and $A / J$ mice from $B[a] P-i n d u c e d$ inflammation}

The protein levels of related inflammatory markers in BEAS-2B cells were determined via Western blot analysis. The protein levels of IL-1 $\beta$ (Fig. $5 \mathrm{a}$ and $\mathrm{b}$ ) in the culture supernatants and the protein levels of pro-IL-1 $\beta$ (Fig. 5a and c) and IL-1 $\beta$ (Fig. 5a and d) in the cell lysates of $\mathrm{B}[\mathrm{a}] \mathrm{P}$-treated cells were markedly higher than those in the supernatants and lysates of control cells (given water), respectively $(p<0.001)$. In contrast to $\mathrm{B}[\mathrm{a}] \mathrm{P}$ exposure alone (in the model group), exposure to $\mathrm{B}$ [a]P plus $12.5,25$ or $50 \mathrm{~g} / \mathrm{kg} \mathrm{H}$. cordata for $24 \mathrm{~h}$ significantly decreased the IL-1 $\beta$ protein levels in the culture supernatants (Fig. 5a and b, $p<0.01$ or $p<0.001$ ), and also significantly reduced the pro-IL-1 $\beta$ (Fig. $5 \mathrm{a}$ and c) and IL-1 $\beta$ (Fig. $5 \mathrm{a}$ and $\mathrm{d}$ ) protein levels in the cell lysates in a dose-dependent manner $(p<0.01$ or $p<$ 0.001). Similar results were also observed for 2undecanone, as incubation with $\mathrm{B}[\mathrm{a}] \mathrm{P}$ plus 25,50 or 100 $\mu \mathrm{M}$ 2-undecanone for $24 \mathrm{~h}$ significantly attenuated the $\mathrm{B}[\mathrm{a}] \mathrm{P}$-induced increases in IL-1 $\beta$ protein levels in the culture supernatants (Fig. 5e and f, $p<0.001$ ), and also notably diminished the $\mathrm{B}[\mathrm{a}] \mathrm{P}$-induced increases in pro-IL-1 $\beta$ (Fig. 5e and g) and IL-1 $\beta$ (Fig. 5e and h) protein levels in the cell lysates in a dose-dependent manner $(p<0.001)$. The IL-1 $\beta$ levels in the plasma of the mice were detected by ELISA. Both $H$. cordata and 2-undecanone treatment along with $\mathrm{B}[\mathrm{a}] \mathrm{P}$ significantly downregulated IL-1 $\beta$ levels compared with the control treatment (given $\mathrm{B}[\mathrm{a}] \mathrm{P}$ or $\mathrm{B}[\mathrm{a}] \mathrm{P}+$ oil) (Fig. 5i, $p<0.01$ or $p<0.001)$.

\section{H. cordata and 2-undecanone decrease the B[a]P-induced over production of intracellular ROS}

As shown in Fig. $6 a$, incubation of cells with B[a]P at 5 $\mu \mathrm{M}$ significantly increased intracellular ROS production in a time-dependent manner $(p<0.001)$. The results of Western blot analysis and immunofluorescence assays confirmed that incubation with $\mathrm{B}[\mathrm{a}] \mathrm{P}$ could significantly increase p-H2A.X expression (Fig. 6b and c, $p<0.001$ ), 


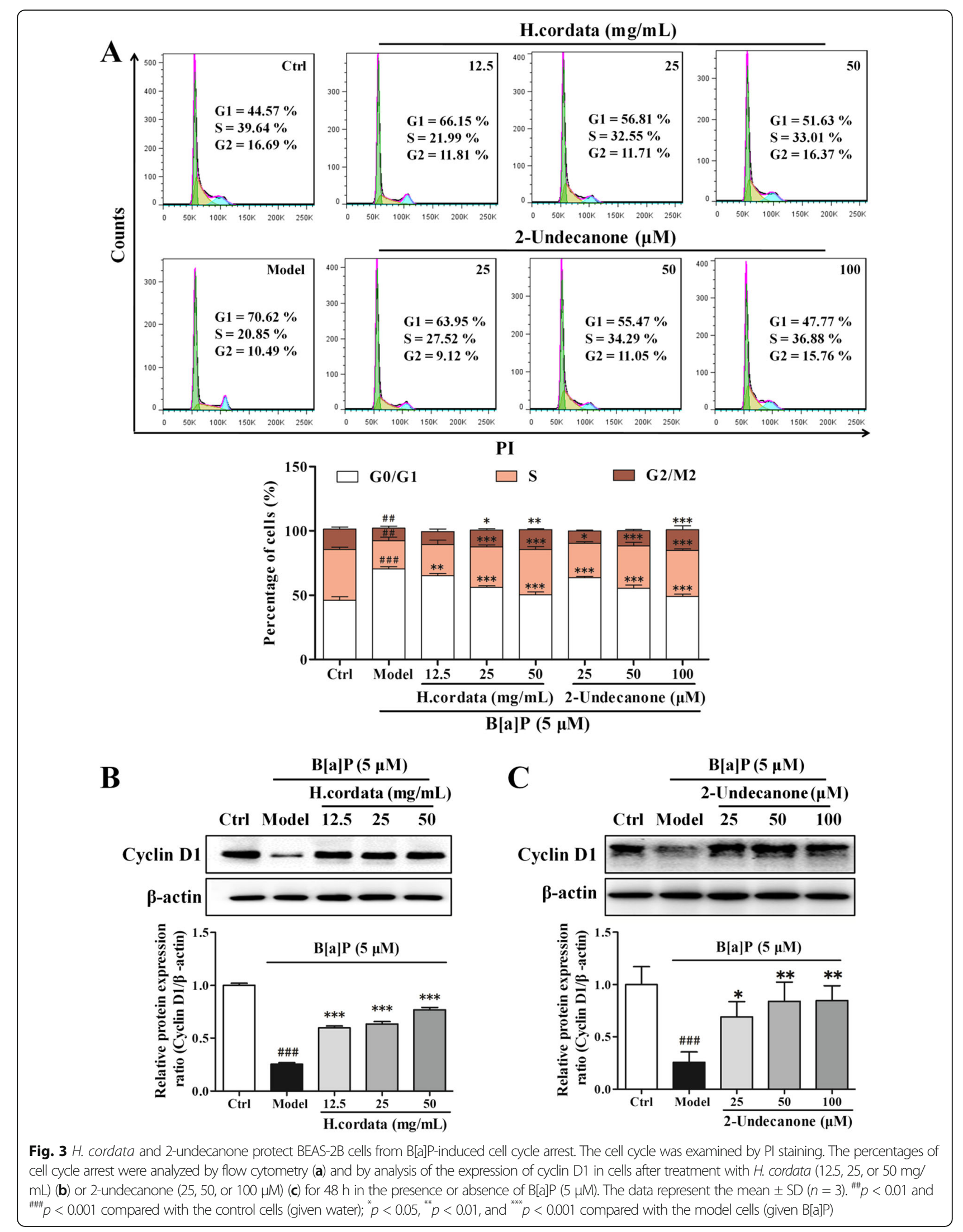


A

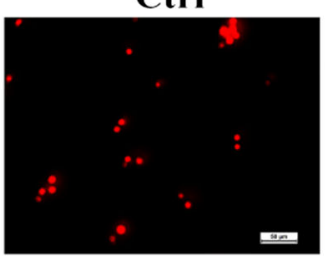

Model

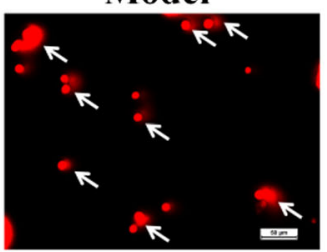

H.cordata (mg/mL)

12.5

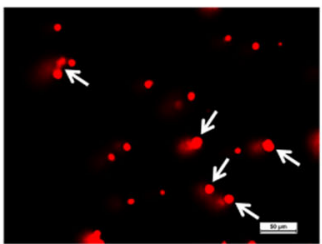

25

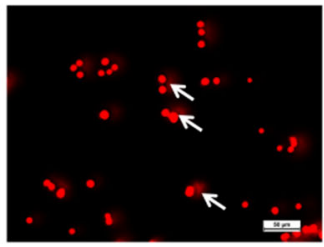

2-Undecanone $(\mu \mathrm{M})$
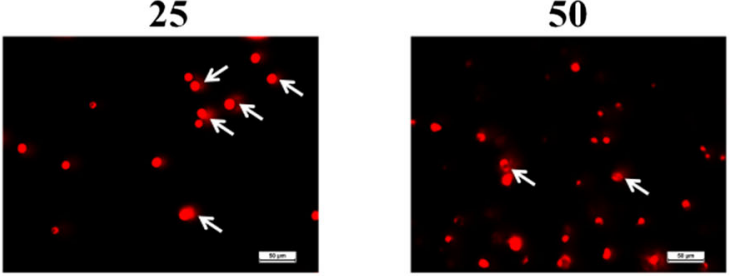

100

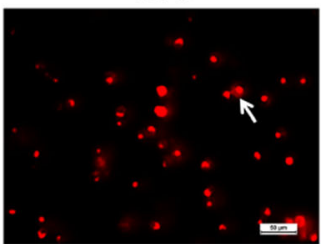

E

C
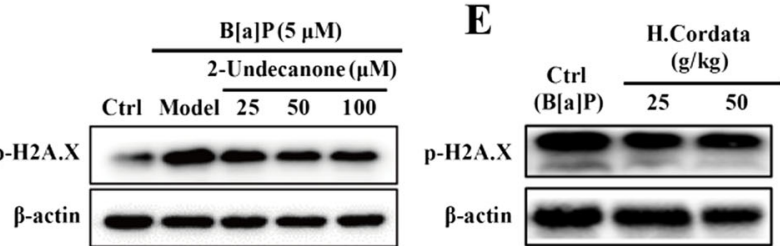

F
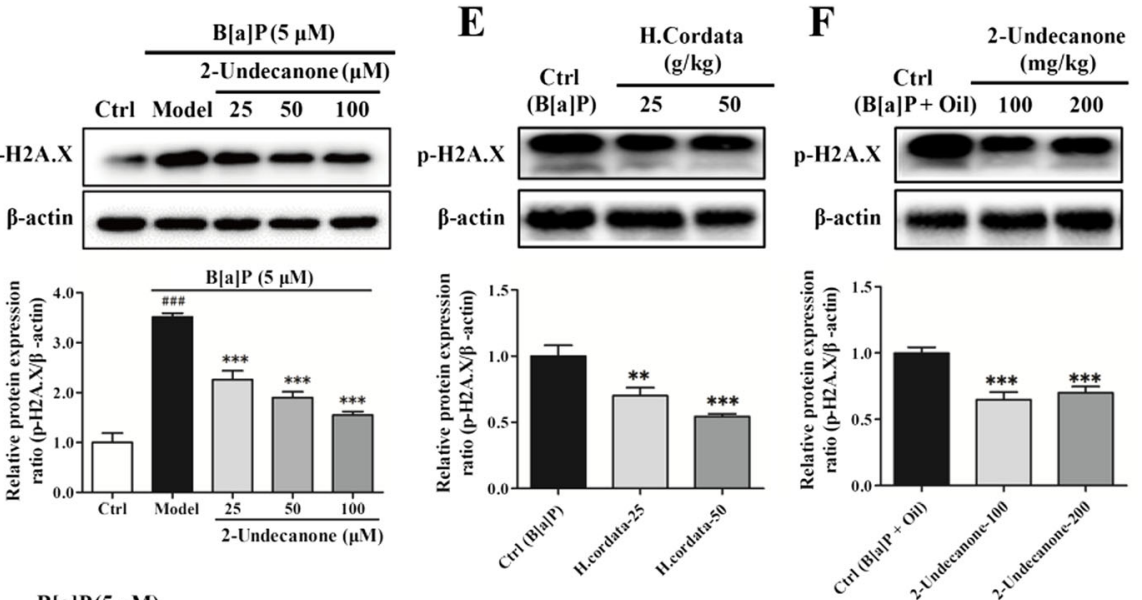

D

$\mathrm{B}|\mathrm{a}| \mathrm{P}(5 \mu \mathrm{M})$
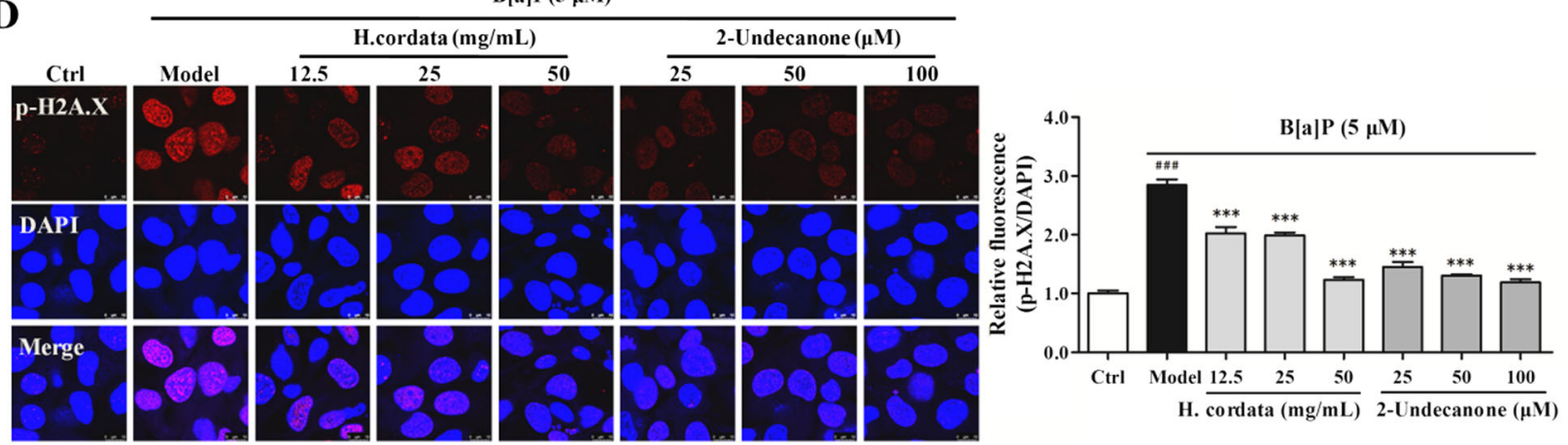

Fig. $4 \mathrm{H}$. cordata and 2-undecanone protect BEAS-2B cells and A/J mice from B[a]P-induced DNA damage. a Representative comet tail images (scale bar: $50 \mu \mathrm{m}$ ) showing the DNA damage response after treatment with vehicle, B[a]P $(5 \mu \mathrm{M})$ alone, B[a]P $(5 \mu \mathrm{M})$ plus H.cordata $(12.5,25$, or 50 $\mathrm{mg} / \mathrm{mL})$, or $\mathrm{B}[\mathrm{a}] \mathrm{P}(5 \mu \mathrm{M})$ plus 2-undecanone $(25,50$, or $100 \mu \mathrm{M})$ for $48 \mathrm{~h}$. The protein levels of the DNA damage marker p-H2A.X were detected in the cells after the same treatment regimens with $\mathrm{H}$. cordata (b) or 2-undecanone (c) by Western blot analysis. $\mathbf{d}$ Representative confocal images (scale bar: $50 \mu \mathrm{m}$ ) of double-stained cells subjected to the described treatments and stained for P-H2A.X (red) and with DAPI (blue). e The protein levels of p-H2A.X were detected in mice after treatment with H.cordata (25 or $50 \mathrm{~g} / \mathrm{kg})(\mathbf{e})$ or 2-undecanone (100 or $200 \mathrm{mg} / \mathrm{kg})(\mathrm{F}) \mathrm{by} \mathrm{Western}$ blot analysis. The data represent the mean $\pm \mathrm{SD}(n=3)$. ${ }^{\# \#} p<0.001$ compared with the control cells (given water); ${ }^{*} p<0.05,{ }^{* * *} p<0.01$, and ${ }^{* * *} p$ $<0.001$ compared with the model cells (given $\mathrm{B}[\mathrm{a}] \mathrm{P})$ 
A

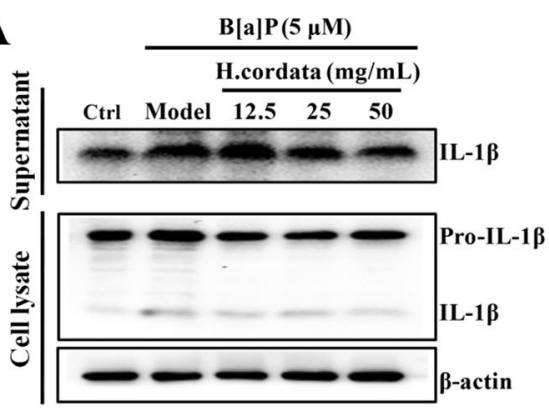

B

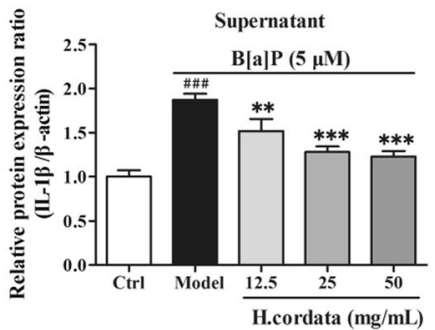

C

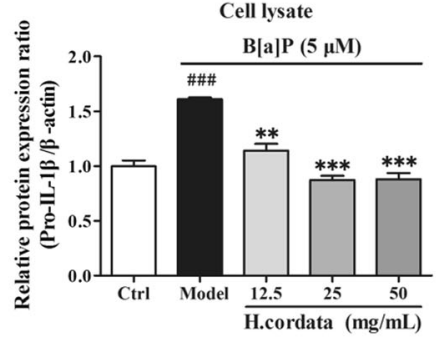

D

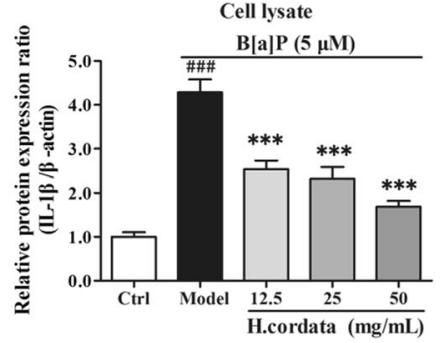

I

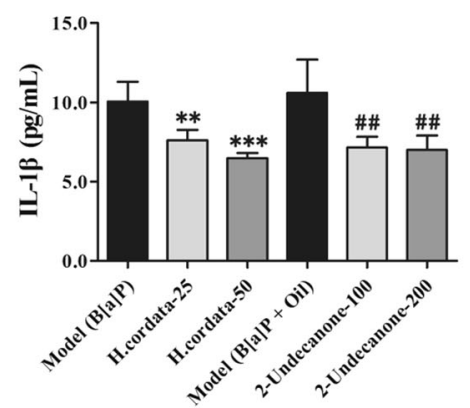

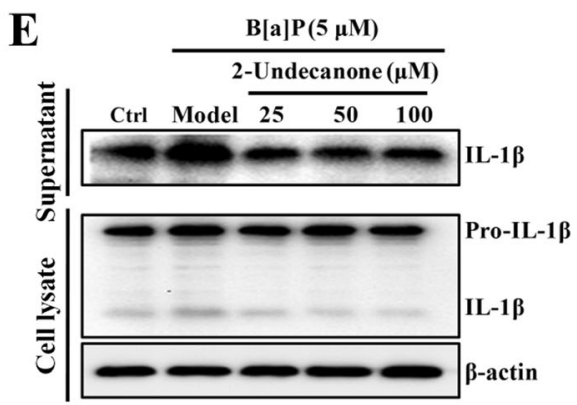

F

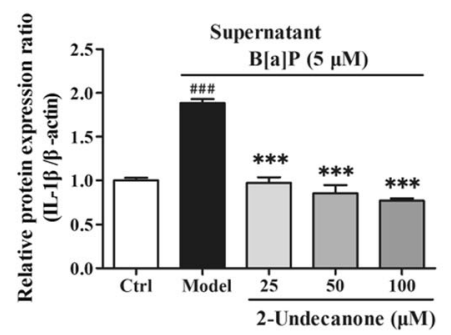

G

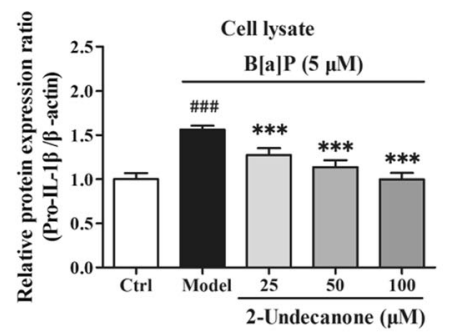

H

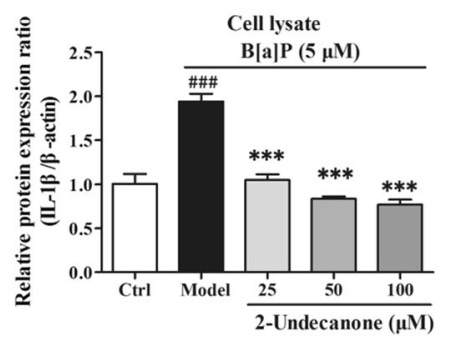

Fig. $5 \mathrm{H}$. cordata and 2-undecanone protect BEAS-2B cells and A/J mice from B[a]P-induced inflammation. The protein levels were measured by using Western blot analysis. $\mathbf{a}$ and $\mathbf{b}$ The protein levels of $\mathrm{IL}-1 \beta$ in the culture supernatants were detected after treatment with vehicle, $\mathrm{B}[\mathrm{a}] \mathrm{P}(5$ $\mu \mathrm{M})$ alone, or B[a]P $(5 \mu \mathrm{M})$ plus H.cordata $(12.5,25$, or $50 \mathrm{mg} / \mathrm{mL})$ for $24 \mathrm{~h}$. The protein levels of pro-IL-1 $\beta$ (a and $\mathbf{c}$ ) and IL-1 $\beta$ (a and $\mathbf{d})$ in the cell lysates were detected after the same H.cordata treatments. (e and $\mathbf{f}$ ) The protein levels of $\mathrm{IL}-1 \beta$ in the culture supernatants were detected after treatment with vehicle, B[a]P $(5 \mu \mathrm{M})$ alone, or B[a]P $(5 \mu \mathrm{M})$ plus 2-undecanone $(25,50$, or $100 \mu \mathrm{M})$ for $24 \mathrm{~h}$. The protein levels of pro-IL-1 13 (e and g) and IL-1 $\beta(E$ and $H)$ in the cell lysates were detected after the same 2-undecanone treatments. $\mathbf{i}$ The IL-1 $\beta$ levels in the plasma of mice were

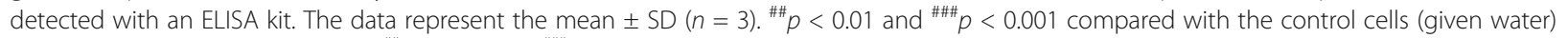
or control mice (given B[a]P + oil); ${ }^{* *} p<0.01$ and ${ }^{* * *} p<0.001$ compared with the model cells (given B[a]P) or control mice (given B[a]P) 


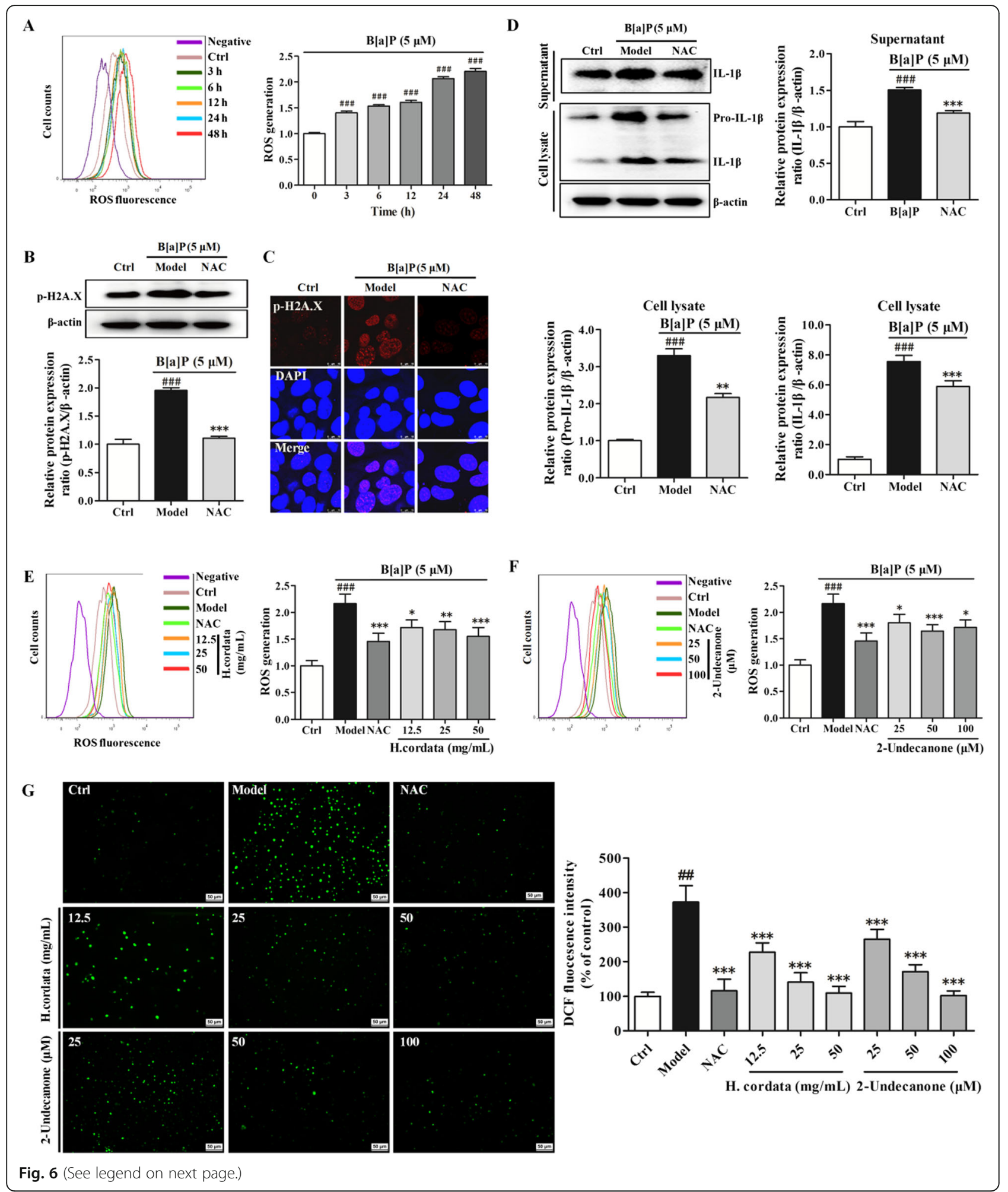

while exposure to NAC ( $2 \mathrm{mM}, 48 \mathrm{~h}$ ), a well-known ROS inhibitor, markedly reversed the $\mathrm{B}[\mathrm{a}] \mathrm{P}$-induced $\mathrm{p}-\mathrm{H} 2 \mathrm{~A}$.X overexpression (Fig. $6 \mathrm{~b}$ and $\mathrm{c}, p<0.001$ ). Exposure to $\mathrm{NAC}$ along with $\mathrm{B}[\mathrm{a}] \mathrm{P}$ also significantly attenuated the $\mathrm{B}[\mathrm{a}] \mathrm{P}$-induced increases in pro-IL- $1 \beta$ and IL-1 $\beta$ protein levels in both the cell lysates and cell culture supernatants (Fig. $6 \mathrm{~d}, p<0.01$ or $p<0.001$ ). Thus, the results indicated that the $\mathrm{B}[\mathrm{a}] \mathrm{P}$-induced overproduction of intracellular ROS could induce DNA damage and inflammation. The results from flow cytometry showed 
(See figure on previous page.)

Fig. $6 \mathrm{H}$. cordata and 2-undecanone decrease the overproduction of intracellular ROS induced by B[a]P. a Intracellular ROS levels were detected by flow cytometry after exposure to B[a]P $(5 \mu \mathrm{M})$ for $0-48$ h. $\mathbf{b}$ and $\mathbf{c}$ p-H2A.X expression in cells after treatment with vehicle, B[a]P $(5 \mu \mathrm{M})$ alone, or B[a]P $(5 \mu \mathrm{M})$ plus NAC (2 mM) for $48 \mathrm{~h}$ was detected by Western blot analysis and immunofluorescence analysis. $\mathbf{d}$ The protein levels of IL-1 $\beta$ in the culture supernatants and of pro-IL-1 $\beta$ and IL-1 $\beta$ in the cell lysates after the same treatments were detected by Western blot analysis. e and f Intracellular ROS levels were detected by flow cytometry after treatment with vehicle, B[a]P $(5 \mu \mathrm{M})$ alone, B[a]P $(5 \mu \mathrm{M})$ plus $\mathrm{H}$.cordata $(12.5,25$, or $50 \mathrm{mg} / \mathrm{mL}$ ) or B[a]P $(5 \mu \mathrm{M})$ plus 2-undecanone $(25,50$, or $100 \mu \mathrm{M})$ for $48 \mathrm{~h}$. g Intracellular ROS generation was detected by fluorescence microscopy (scale bar: $50 \mu \mathrm{m})$ after treatment with vehicle, B[a]P $(5 \mu \mathrm{M})$ alone, B[a]P $(5 \mu \mathrm{M})$ plus H.cordata $(12.5,25$, or $50 \mathrm{mg} / \mathrm{mL})$ or B[a]P $(5 \mu \mathrm{M})$ plus 2-undecanone $(25,50$, or $100 \mu \mathrm{M}$ ) for $48 \mathrm{~h}$. The data represent the mean \pm SD $(n=3)$. ${ }^{\# \# \#} p<0.001$ compared with the control cells (given water); ${ }^{*} p<0.05,{ }^{* *} p<0.01$, and ${ }^{* * *} p<$ 0.001 compared with the model cells (given B[a]P).

that exposure to $H$. cordata at $12.5,25$ or $50 \mathrm{~g} / \mathrm{kg}$ for 48 $\mathrm{h}$ significantly decreased the $\mathrm{B}[\mathrm{a}] \mathrm{P}$-mediated intracellular ROS overproduction in a dose-dependent manner (Fig. 6e, $p<0.05, p<0.01$ or $p<0.001$ ) in the treated cells compared with the B[a]P model cells. Treatment with 2undecanone at 25,50 or $100 \mu \mathrm{M}$ for $48 \mathrm{~h}$ also significantly reduced the intracellular ROS overproduction induced by $\mathrm{B}[\mathrm{a}] \mathrm{P}$ (Fig. 6f, $p<0.05$ or $p<0.001$ ). Intracellular ROS generation was also detected by fluorescence microscopy. Similar results were observed; B[a]P treatment increased intracellular ROS production compared with the control (water) treatment. However, incubation of $\mathrm{B}[\mathrm{a}] \mathrm{P}$-treated cells with $H$. cordata or 2undecanone notably diminished $\mathrm{B}[\mathrm{a}] \mathrm{P}$-induced ROS overproduction (Fig. 6g). The correlation between ROS levels and DNA damage or inflammation was analyzed by using Pearson analysis. The results showed that the decrease in ROS levels was closely and positively related to the reductions in DNA damage (Additional file 1: Figure $\mathrm{S} 4, p<0.05$ ) and inflammation (Additional file 1 : Figure $\mathrm{S} 5, p<0.05)$ mediated by $H$. cordata and 2undecanone.

\section{H. cordata and 2-undecanone activate the Nrf2 signaling pathway}

The protein levels of Nrf2, HO-1 and NQO-1 in BEAS$2 \mathrm{~B}$ cells and $\mathrm{A} / \mathrm{J}$ mice were determined via Western blot analysis and immunohistochemistry, respectively. As shown in Fig. 7a, compared with those of control cells (given water), whole-cell lysates of cells incubated with H. cordata $(25 \mathrm{~g} / \mathrm{kg})$ or 2-undecanone $(50 \mu \mathrm{M})$ exhibited significantly increased protein levels of $\mathrm{Nrf} 2, \mathrm{HO}-1$ and NQO-1 $(p<0.01$ or $p<0.001)$. The same H. cordata or 2 -undecanone treatment also resulted in significant increases in nuclear Nrf2 protein levels (Fig. 7b, $p<0.001$ ) . tBHQ, a known inducer of Nrf2, was used as a positive control and markedly upregulated the total and nuclear Nrf2 protein levels (Fig. 7a and $b, p<0.001$ ). The immunofluorescence results also showed that both $H$. cordata and 2-undecanone notably promoted the translocation of Nrf2 from the cytoplasm to the nucleus (Fig. 7c). Furthermore, treatment with $\mathrm{B}[\mathrm{a}] \mathrm{P}$ at $5 \mu \mathrm{M}$ significantly decreased the protein levels of Nrf2, HO-1 and NQO-1 in whole-cell lysates (Fig. 7d, $p<0.001$ ) and decreased nuclear Nrf2 protein levels (Fig. 7e, $p<0.001$ ) - In contrast, treatment with $H$. cordata or 2undecanone markedly attenuated the downregulation of Nrf2, HO-1 and NQO-1 expression induced by B[a]P (Fig. $7 \mathrm{~d}$ and e, $p<0.01$ or $p<0.001$ ). Furthermore, immunohistochemistry was performed to detect the expression of Nrf2, HO-1 and NQO-1 in the lung tissues of mice. Compared with the control treatment (given $\mathrm{B}[\mathrm{a}] \mathrm{P}$ or $\mathrm{B}[\mathrm{a}] \mathrm{P}+$ oil), both $H$. cordata and 2-undecanone treatment strikingly enhanced the expression of Nrf2, HO- 1 and NQO-1 in a dose-dependent manner (Fig. 7f$\mathrm{k}, p<0.001)$.

\section{Nrf2-HO-1/NQO-1 signaling pathway mediates the protective effects of $H$. cordata and 2-undecanone against $\mathrm{B}[\mathrm{a}] \mathrm{P}$-induced DNA damage, inflammation and cytotoxicity}

To explore the mediating effect of Nrf2 on the protective effects of $H$. cordata and 2-undecanone against $\mathrm{B}[\mathrm{a}] \mathrm{P}$-induced DNA damage and inflammation, Nrf2 expression was silenced in BEAS-2B cells by transfection with two Nrf2-specific siRNAs (siNrf2-1 and siNrf2-2). Cells transfected with siNrf2 showed significant reductions in Nrf2 expression compared to cells transfected with control siRNA (siCtrl) (Additional file 1: Figure S6, $p<0.001$ ). Compared with cells transfected with siCtrl, cells transfected with siNrf2-1 or siNrf2-2 exhibited significant attenuations in the $H$. cordata- and 2undecanone-enhanced protein levels of HO-1 (Fig. 8a and b, $p<0.01$ or $p<0.001$ ) and NQO-1 (Fig. $8 \mathrm{c}$ and d, $p<0.01$ or $p<0.001)$. It was further observed that the reduction in $\mathrm{B}[\mathrm{a}] \mathrm{P}$-induced ROS overproduction caused by $H$. cordata and 2-undecanone could be markedly attenuated by transfection with siNrf2-1 or siNrf2-2 (Fig. $8 \mathrm{e}$ and $\mathrm{f}, p<0.001$ ).

In contrast to transfection with siCtrl, transfection with siNrf2-1 or siNrf2-2 markedly attenuated the $H$. cordata and 2-undecanone-mediated decreases in $\mathrm{B}[\mathrm{a}] \mathrm{P}$ induced high p-H2A.X expression (Fig. 9a and b). In addition, the culture supernatants of cells transfected with siNrf2-1 or siNrf2-2 and incubated with $H$. cordata or 2-undecanone showed no changes or weak reductions in the $\mathrm{B}[\mathrm{a}] \mathrm{P}$-induced high expression of IL-1 $\beta$ (Fig. 9c and d). Furthermore, the protective effects of $H$. cordata 


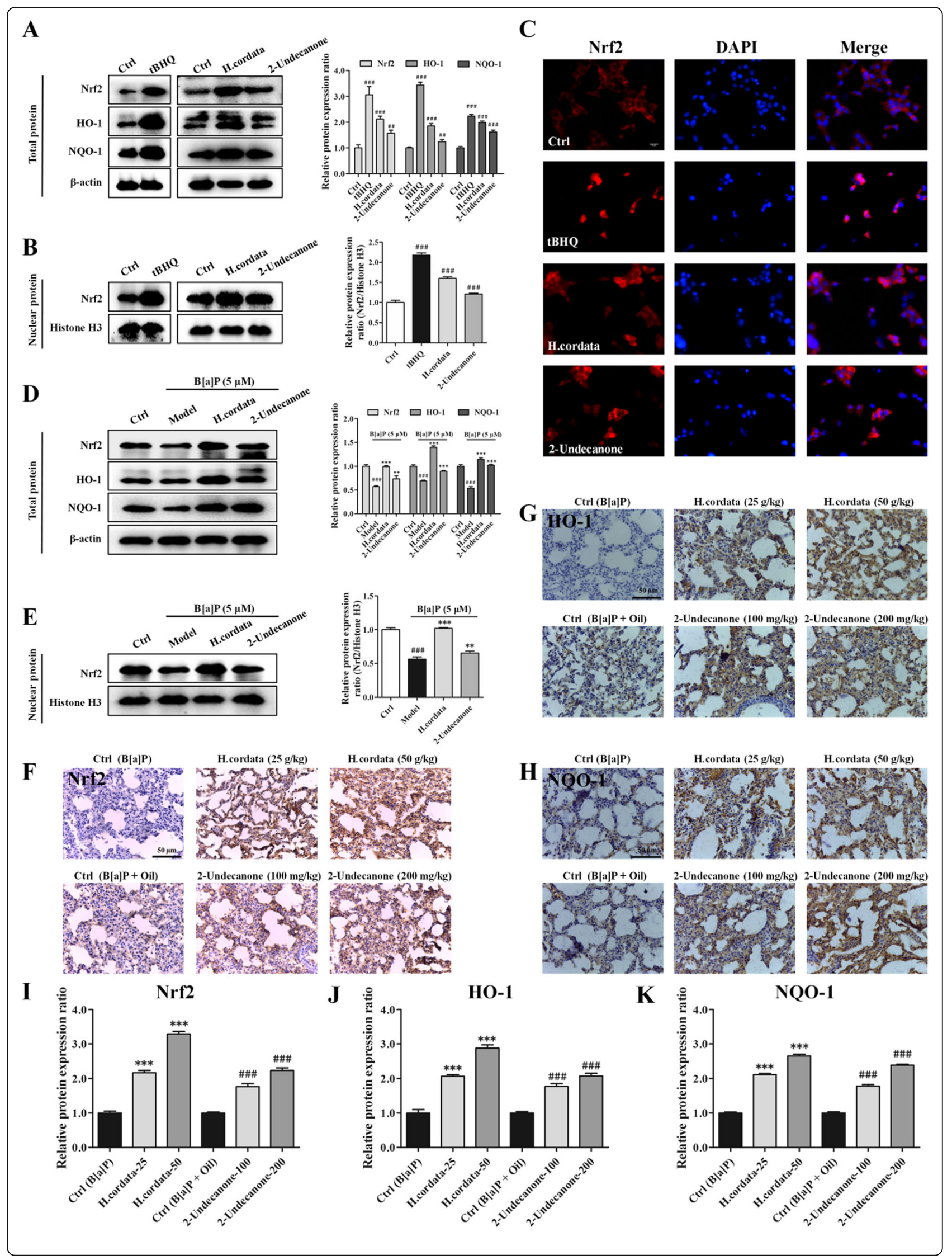


(See figure on previous page.)Fig. $7 \mathrm{H}$. cordata and 2-undecanone activate the Nrf2 signaling pathway. The protein levels were measured by using Western blot analysis. Tertiary butylhydroquinone (tBHQ), a well-known Nrf2 activator, was used as a positive control. a The total protein levels of Nrf2, HO-1 and NQO-1 were measured in cells exposed to vehicle, tBHQ $(10 \mu \mathrm{M}), \mathrm{H}$. cordata $(25 \mathrm{mg} / \mathrm{mL})$ or 2-undecanone $(50 \mu \mathrm{M})$. $\mathbf{b}$ The nuclear Nrf2 protein levels were measured in cells subjected to the same treatments. c Representative confocal images (scale bar: $50 \mu \mathrm{m}$ ) of double-stained cells subjected to the described treatments and stained for Nrf2 (red) and with DAPI (blue). d The total protein levels of Nrf2, HO1 and NQO-1 were measured in cells exposed to vehicle, B[a]P $(5 \mu \mathrm{M})$ alone, B[a]P $(5 \mu \mathrm{M})$ plus H.cordata $(25 \mathrm{mg} / \mathrm{mL})$ or B[a]P $(5 \mu \mathrm{M})$ plus 2undecanone $(50 \mu \mathrm{M})$. (E) The nuclear Nrf2 protein levels were measured in cells subjected to the same treatments. (F-K) The expression of Nrf2, HO-1 and NQO-1 in the lung tissues of mice after treatment was detected by immunohistochemistry. The data represent the mean \pm SD $(n=3)$. ${ }^{* *} p<0.01$ and ${ }^{* * *} p<0.001$ compared with the model cells (given B[a]P) or control mice (given B[a]P); ${ }^{\# \# \#} p<0.001$ compared with the control cells (given water) or control mice (given B[a]P + oil)

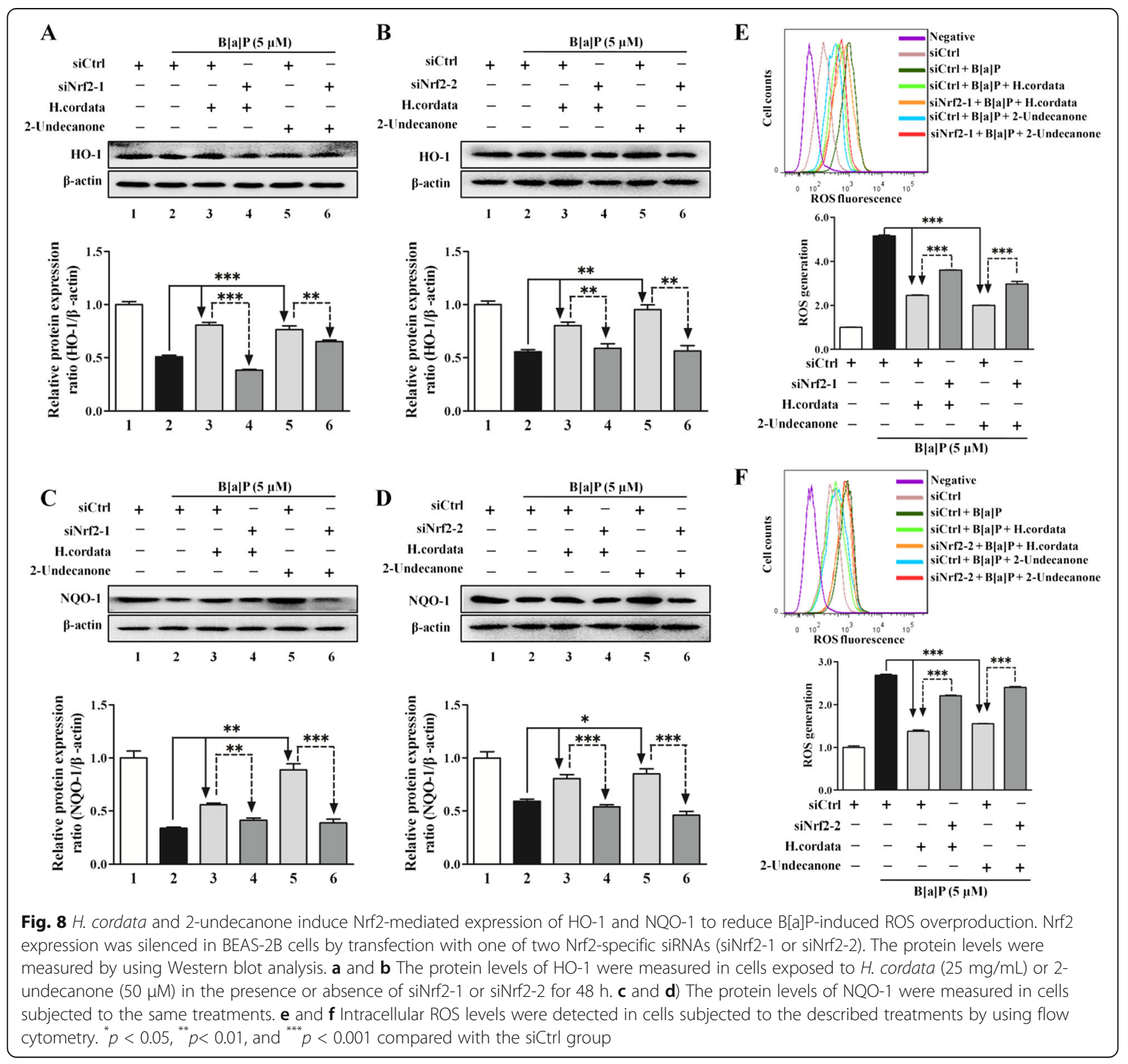



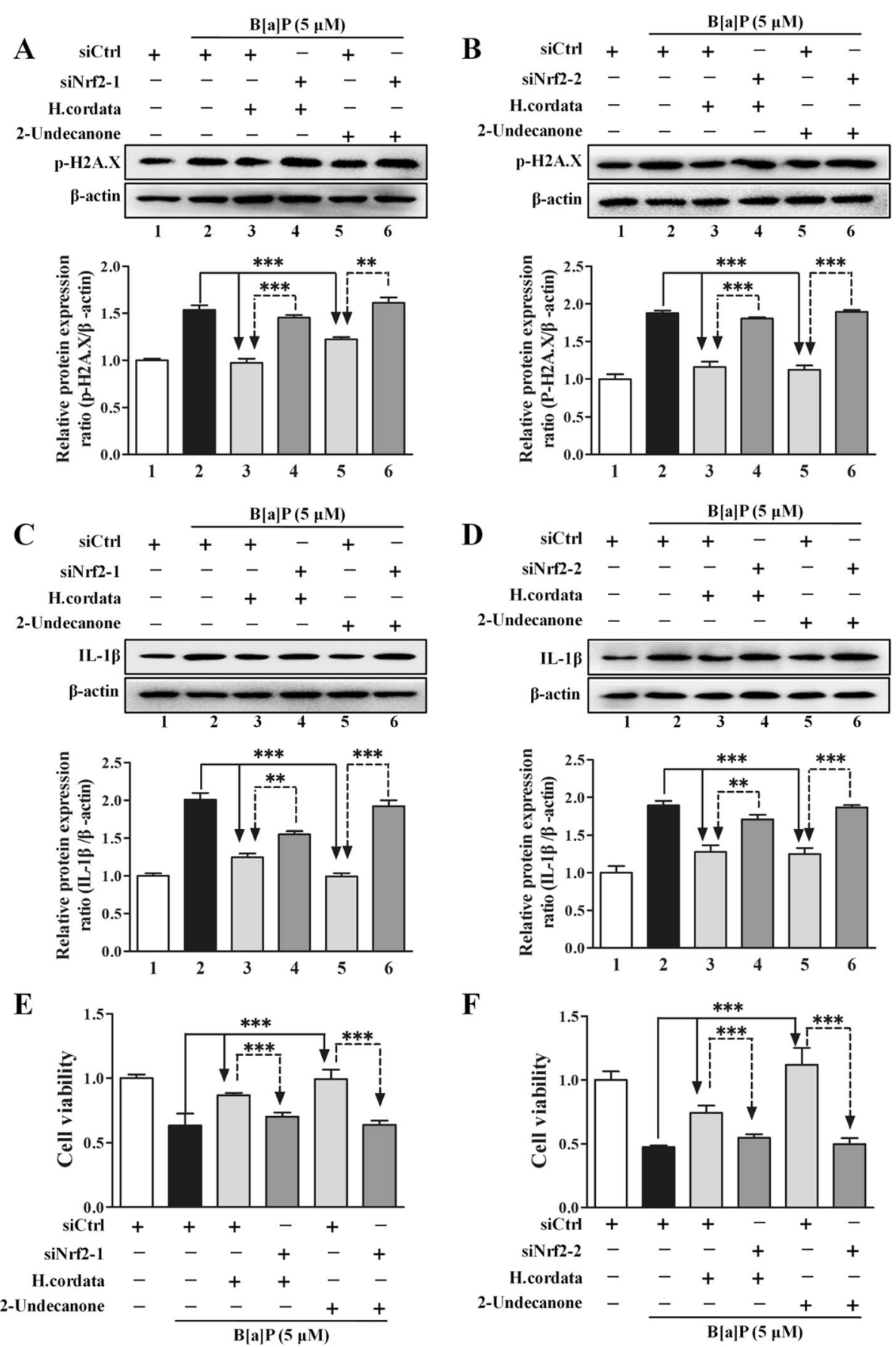

Fig. 9 The Nrf2-HO-1/NQO-1 signaling pathway mediates the protective effects of $\mathrm{H}$. cordata and 2-undecanone against B[a]P-induced DNA damage, inflammation and cytotoxicity. The protein levels were measured by using Western blot analysis. Cell viability was determined by MTT assay. $\mathbf{a}$ and $\mathbf{b}$ The protein levels of p-H2A.X were measured in cells exposed to $\mathrm{H}$. cordata $(25 \mathrm{mg} / \mathrm{mL})$ or 2-undecanone $(50 \mu \mathrm{M})$ in the presence or absence of siNrf2-1 or siNrf2-2 for $48 \mathrm{~h}$. $\mathbf{c}$ and $\mathbf{d}$ The protein levels of IL-1 $\beta$ in cell culture supernatants were measured after treatment of cells with H. cordata $(25 \mathrm{mg} / \mathrm{mL})$ or 2-undecanone $(50 \mu \mathrm{M})$ in the presence or absence of siNrf2-1 or siNrf2-2 for $24 \mathrm{~h}$. e and $\mathbf{f}$ Cell viability was determined after treatment of cells with $\mathrm{H}$. cordata $(25 \mathrm{mg} / \mathrm{mL})$ or 2 -undecanone $(50 \mu \mathrm{M})$ in the presence or absence of siNrf2-1 or siNrf2-2. ${ }^{* *} p<$ 0.01 and ${ }^{* * *} p<0.001$ compared with the siCtrl group

and 2-undecanone against $\mathrm{B}[\mathrm{a}] \mathrm{P}$-induced cytotoxicity could be markedly attenuated by siNrf2 transfection (Fig. 9e and f).

\section{Discussion}

Lung cancer is the most prevalent malignancy and is the leading cause of cancer death in men and the second 


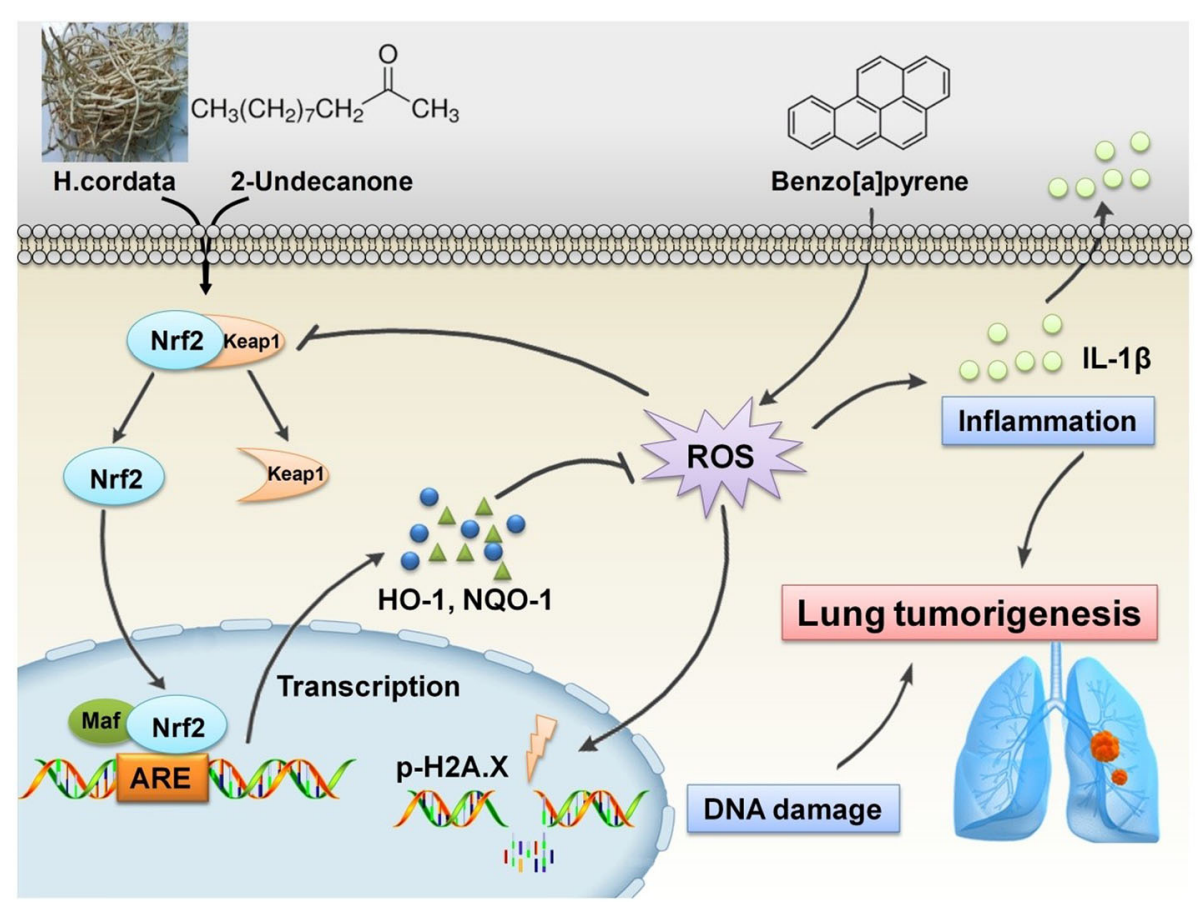

Fig. 10 Schematic diagram of mechanism on this research. H. cordata and 2-undecanone could effectively activate the Nrf2 pathway to induce the expression of the antioxidative enzymes HO-1 and NQO-1 and thus to counteract intracellular ROS generation, thereby attenuating DNA damage and inflammation caused by B[a]P stimulation and playing a role in the chemoprevention of B[a]P-induced lung carcinogenesis

leading cause of death in women [1]. B[a]P, which is mostly produced from cigarette smoking or car exhausts, acts as a potent carcinogen that leads to lung carcinogenesis [28]. Chemoprevention has been the most promising strategy to effectively decrease the incidence and mortality of lung cancer, especially for B[a]P-induced carcinogenesis in smoking patients $[5,6]$. In the current study, we investigated the chemopreventive effects of $H$. cordata, a widely used herbal medicine with antiinflammatory and antioxidative properties, against lung tumorigenesis and further clarified the underlying mechanisms. The results of this study will enhance understanding of the protective effect of $H$. cordata against $\mathrm{B}[\mathrm{a}] \mathrm{P}$-stimulated lung tumorigenesis.

First, a $\mathrm{B}[\mathrm{a}] \mathrm{P}$-stimulated lung adenocarcinoma animal model in A/J mice was successfully established to investigate the chemopreventive effects of $H$. cordata and its main bioactive compound 2-undecanone against lung cancer (Fig. 1a). A/J mice, which are highly susceptible to carcinogen-induced tumors, have been widely used as appropriate in vivo models to study the chemoprevention of lung carcinogenesis [5, 44]. The results showed that both $\mathrm{H}$. cordata and 2-undecanone significantly reduced tumor numbers in $\mathrm{B}[\mathrm{a}] \mathrm{P}$-treated mice in a dosedependent manner compared to $\mathrm{B}[\mathrm{a}] \mathrm{P}$ alone (Fig. 1c). Moreover, the results obtained with the established $\mathrm{B}$ [a]P-treated BEAS-2B cell model showed that both H.cordata and 2-undecanone could effectively protect normal BEAS-2B cells from $\mathrm{B}[\mathrm{a}] \mathrm{P}$-induced injury in a dose-dependent manner (Figs. 2 and 3). The combined results suggested that H.cordata could effectively prevent normal lung cells from $\mathrm{B}[\mathrm{a}] \mathrm{P}$-initiated lung tumorigenesis and that 2-undecanone could be the bioactive compound responsible for this pharmacological activity.

Numerous chemopreventive agents have been developed, such as tamoxifen, raloxifene, finasteride, and celecoxib. However, the use of these agents for cancer prevention is restricted because of their severe side effects after long-term administration [4]. This issue clearly indicates that safe and efficacious agents are urgently needed for cancer prevention. Various herbal medicines and diet-derived natural products maybe candidates for this purpose. H. cordata is well known as a widely used medicinal herb with a variety of pharmacological functions $[30,31]$ and is also popularly consumed as a healthy vegetable in East Asia [32]. Thus, the toxicity of $H$. cordata was also determined in vivo and in vitro in this current study. Our data revealed no significant body weight differences between $\mathrm{B}[\mathrm{a}] \mathrm{P}$ control group $\mathrm{A} / \mathrm{J}$ mice and treatment group $\mathrm{A} / \mathrm{J}$ mice during the experiment (Fig. 1b). Moreover, no considerable differences were observed in the indexes of the heart, kidney, thymus, liver and spleen between the B[a]P control group and the treatment groups (Fig. 1d). In addition, incubation with H.cordata or 2-undecanone alone could not produce toxicity in normal BEAS-2B cells (Fig. 2a 
and b). These preliminary data implied that H.cordata could be a potential effective agent for the chemoprevention of lung carcinogenes is that does not cause severe systemic toxicity.

$\mathrm{B}[\mathrm{a}] \mathrm{P}$-induced excessive production of ROS, which results in oxidative stress, can severely damage DNA structure and is a prerequisite for $\mathrm{B}[\mathrm{a}] \mathrm{P}$-associated tumorigenesis [10-12]. It has been reported that DNA damage is significantly associated with increased lung cancer risk and is considered to be the primary cause of lung cancer development $[45,46]$. The roles of DNA damage repair pathways in cancers have attracted widespread interest in the clinic and have been widely recognized as vital targets to improve lung cancer therapy [47]. Hence, the effects of $H$. cordata and 2-undecanone on $\mathrm{B}[\mathrm{a}] \mathrm{P}$-induced DNA damage were further investigated. The results from the comet assay showed that $H$. cordata and 2-undecanone could notably reduce the fluorescence in migrated DNA and the tails of disrupted DNA fragments (Fig. 4a), suggesting that $H$. cordata and 2-undecanone could effectively reverse $\mathrm{B}[\mathrm{a}] \mathrm{P}$-induced DNA damage. The levels of p-H2A.X, which is a verified marker for DNA double-strand breaks and is involved in the response to DNA damage [41-43], were determined in vitro and in vivo. The results showed that exposure to $H$. cordata or 2-undecanone significantly decreased the $\mathrm{B}[\mathrm{a}] \mathrm{P}$-induced overexpression of $\mathrm{p}-\mathrm{H} 2 \mathrm{~A}$.X in a dosedependent manner in the cells (Fig. 4b-d). p-H2A.X protein levels in the lung tissues of mice were further determined. It was observed that both $H$. cordata and 2undecanone significantly downregulated p-H2A.X expression in $\mathrm{B}[\mathrm{a}] \mathrm{P}$-treated mice compared with $\mathrm{B}[\mathrm{a}] \mathrm{P}$ treatment alone (Fig. 4e and f). Our results indicated that $H$. cordata and 2-undecanone could effectively reverse $\mathrm{B}[\mathrm{a}] \mathrm{P}$-induced DNA damage in vitro and in vivo.

In addition to DNA damage, oxidative stress-induced inflammation is also a major contributor to lung cancer initiation and progression [13, 14]. Mature and biologically active IL-1 $\beta$, which is generated from the inactive precursor cytokine pro-IL- $1 \beta$ and then secreted, is a critical regulator of the inflammatory response $[48,49]$. IL$1 \beta$ is involved in a variety of cellular activities, including cell proliferation, differentiation, and apoptosis [50]. Moreover, inflammation in the tumor microenvironment mediated by IL- $1 \beta$ is hypothesized to play a major role in cancer invasiveness, progression, and metastasis [5153]. Studies on tumor immunosurveillance have proposed a strong relationship between lung cancer risk factors and alterations in IL-1 $\beta$ levels [54]. Antiinflammatory therapy targeting the IL- $1 \beta$ innate immunity pathway can significantly reduce incident lung cancer and lung cancer mortality [55]. Hence, the effects of $H$. cordata and 2-undecanone on B[a]P-induced inflammation were also investigated. The results showed that treatment of cells with $H$. cordata or 2-undecanone significantly decreased the $\mathrm{B}[\mathrm{a}] \mathrm{P}$-induced overexpression of IL-1 $\beta$ in the cell culture supernatants (Fig. 5 a, b, e and $\mathrm{f})$. The same treatments also markedly decreased the high levels of pro-IL-1 $\beta$ and IL-1 $\beta$ induced by B[a]P in the cell lysates (Fig. 5a, c, d, e, g and h), suggesting that $H$. cordata and 2-undecanone could effectively reduce IL- $1 \beta$ secretion, thereby potentially reducing the inflammatory response. Furthermore, both $H$. cordata and 2undecanone treatment could significantly downregulate the IL-1 $\beta$ levels in the plasma of the mice exposed to $\mathrm{B}[\mathrm{a}] \mathrm{P}$ (Fig. 5i). Our results implied that $H$. cordata and 2-undecanone could effectively reverse $\mathrm{B}[\mathrm{a}] \mathrm{P}$-induced inflammation in vitro and in vivo.

Then, it was confirmed that incubation of cells with $\mathrm{B}[\mathrm{a}] \mathrm{P}$ could markedly increase intracellular ROS production (Fig. 6a) and notably enhance the expression of pH2A.X (Fig. $6 \mathrm{~b}$ and c), pro-IL-1 $\beta$ and IL-1 $\beta$ (Fig. $6 \mathrm{~d}$ ). However, NAC, a well-known ROS inhibitor, could markedly reverse the $\mathrm{B}[\mathrm{a}] \mathrm{P}$-induced $\mathrm{p}-\mathrm{H} 2 \mathrm{~A}$.X overexpression (Fig. $6 \mathrm{~b}$ and c). ROS reduction by NAC also significantly decreased the high levels of pro-IL-1 $\beta$ and IL$1 \beta$ induced by $B[a] P$ (Fig. $6 \mathrm{~d}$ ). From these results, it was confirmed that DNA damage and inflammation could be significantly reversed by reductions in intracellular ROS levels, suggesting that the $\mathrm{B}[\mathrm{a}] \mathrm{P}$-induced overproduction of intracellular ROS could cause marked DNA damage and inflammation. Therefore, the impact of $H$. cordata and 2-undecanone on of intracellular ROS levels was further investigated. It was observed that both $H$. cordata and 2-undecanone treatment significantly diminished the intracellular ROS overproduction induced by $\mathrm{B}[\mathrm{a}] \mathrm{P}$ (Fig. 6e-g). The correlation between ROS levels and DNA damage or inflammation was analyzed by using Pearson analysis. The results showed that the decrease in ROS levels was closely and positively related to the inhibition of $\mathrm{B}[\mathrm{a}] \mathrm{P}$-induced DNA damage (Additional file 1: Figure S4) or inflammation (Additional file 1: Figure S5) by H. cordata and 2-undecanone. Given all the results, it was speculated that $H$. cordata and 2undecanone could protect cells against $\mathrm{B}[\mathrm{a}] \mathrm{P}$-induced DNA damage or inflammation by reducing intracellular ROS overproduction.

Nrf2 has been identified as a key regulator of the inducible expression of antioxidative enzymes, antiinflammatory proteins and conjugation/detoxification proteins, such as NQO1 and HO-1 [21]. Upon oxidative stress caused by B[a]P or pharmacologic induction, the Nrf2 pathway could be rapidly activated to counteract intracellular ROS generation, thereby attenuating DNA damage and inflammation caused by B[a]P stimulation [21, 22]. The general cytoprotective effect of Nrf2 pathway activation has made it an attractive target for the chemoprevention of $\mathrm{B}[\mathrm{a}] \mathrm{P}$-induced lung carcinogenesis. Hence, the modulatory 
effects of $H$. cordata and 2-undecanone on the Nrf2 pathway were further evaluated to clarify their chemopreventive functions against lung tumorigenesis. It was observed that both $H$. cordata and 2-undecanone significantly increased the protein levels of Nrf2, HO1 and NQO-1 in whole-cell lysates (Fig. 7a) and resulted in significant increases in nuclear Nrf2 protein expression (Fig. 7b). The immunofluorescence results also showed that both $H$. cordata and 2-undecanone notably promoted the translocation of Nrf2 from the cytoplasm to the nucleus (Fig. 7c). Thus, it was implied that $H$. cordata and 2-undecanone could effectively activate the Nrf2 pathway to induce the expression of the antioxidative enzymes $\mathrm{HO}-1$ and $\mathrm{NQO}-1$. Then, it was found that $\mathrm{B}[\mathrm{a}] \mathrm{P}$ significantly decreased the protein levels of Nrf2, HO-1 and NQO-1 in whole-cell lysates (Fig. 7d) and decreased nuclear Nrf2 protein levels (Fig. 7e). In contrast, treatment with $H$. cordata and 2-undecanone markedly reversed the above-mentioned effects of $\mathrm{B}[\mathrm{a}] \mathrm{P}$ on the inhibition of Nrf2, HO-1 and NQO-1 expression (Fig. 7d and e). Moreover, both $H$. cordata and 2undecanone treatment strikingly enhanced the expression of Nrf2, HO-1 and NQO-1 in a dose-dependent manner compared with $\mathrm{B}[\mathrm{a}] \mathrm{P}$ treatment in control mice (Fig. 7f-k). Then, to confirm the role of Nrf2 in the protective effects of $H$. cordata and 2-undecanone against $\mathrm{B}[\mathrm{a}] \mathrm{P}$-induced DNA damage and inflammation, Nrf2 expression was silenced in BEAS-2B cells by transfection with siNrf2-1 or siNrf2-2. The data showed that transfection of cells with siNrf2-1 or siNrf2-2 significantly attenuated the $H$. cordata- and 2-undecanone-induced increases in the protein levels of HO-1 (Fig. 8a and b) and NQO-1 (Fig. 8c and d). The reductions in $\mathrm{B}[\mathrm{a}] \mathrm{P}$-induced $\mathrm{ROS}$ overproduction mediated by $H$. cordata and 2-undecanone could also be markedly diminished by transfection of cells with siNrf2-1 or siNrf2-2 (Fig. 8e and f). Furthermore, the attenuating effects of $H$. cordata and 2-undecanone on $\mathrm{B}[\mathrm{a}] \mathrm{P}$-induced $\mathrm{p}-\mathrm{H} 2 \mathrm{~A} . \mathrm{X}$ overexpression were markedly diminished by siNrf2 transfection (Fig. 9a and b). In addition, the culture supernatants of cells transfected with siNrf2-1 or siNrf2-2 and then treated with $H$. cordata or 2-undecanone showed no changes or weak reductions in the $\mathrm{B}[\mathrm{a}] \mathrm{P}$-induced high levels of IL-1 $\beta$ (Fig. 9c and d). As expected, the protective effects of $H$. cordata and 2-undecanone against $\mathrm{B}[\mathrm{a}] \mathrm{P}$ induced cytotoxicity were also markedly diminished by siNrf2 transfection (Fig. 9e and f). Based on the combined results in vitro and in vivo, it was speculated that $H$. cordata and 2-undecanone could effectively activate the Nrf2 pathway to induce the expression of the antioxidative enzymes $\mathrm{HO}-1$ and NQO-1 and thus to counteract intracellular ROS generation, thereby attenuating DNA damage and inflammation causedby $\mathrm{B}[\mathrm{a}] \mathrm{P}$ stimulation and playing a role in the chemoprevention of $\mathrm{B}[\mathrm{a}] \mathrm{P}$-induced lung carcinogenesis (Fig. 10).

\section{Conclusions}

In conclusion, our studies have shown that $H$. cordata and its bioactive compound 2-undecanone can significantly reduce $\mathrm{B}[\mathrm{a}] \mathrm{P}$-induced $\mathrm{DNA}$ damage and inflammation to prevent lung tumorigenesis by activating the Nrf2-HO-1/NQO-1 signaling pathway. The data from these well-controlled in vitro and in vivo studies indicate that $H$. cordata may exert beneficial effects against cigarette smoke-induced lung inflammation and oxidative DNA damage in the human body. Thus, $H$. cordata could be an effective candidate agent for the chemoprevention of lung cancer.

\section{Additional file}

Additional file 1: Figure S1. The GC-FID chromatogram of standard compound 2-undecanone (A) and H.cordata water extract (B). Figure S2. Representative images showing haematoxylin and eosin staining of lung samples from the different groups. Figure S3. Effects of B[a]P on viability of BEAS-2B cells. Cell viability was examined using the MTT assay. The data represent the mean \pm SD $(n=3)$. ${ }^{\#} p<0.05$ and ${ }^{\# \#} p<0.001$ compared with the control cells (given water). Figure S4. Pairwise correlation between reduction in $\mathrm{B}[\mathrm{a}] \mathrm{P}$-induced $\mathrm{ROS}$ over production and decreased p-H2A.X protein levels ratio in BEAS-2B cells by $\mathrm{H}$. cordata (A) and 2undecanone (B). The correlations were analyzed by using Person analysis. Figure S5. Pairwise correlation between reduction in $\mathrm{B}[\mathrm{a}] \mathrm{P}$-induced ROS over production and decreased protein levels of pro-IL-1 $\beta$ or $I L-1 \beta$ in BEAS-2B cells by $H$. cordata (A) and 2-undecanone (B). The correlations were analyzed by using Person analysis. Figure S6. The efficiency of Nrf2 silencing. Nrf2 expression was silenced in BEAS-2B cells by transfection of three Nrf2-specific siRNA (siNrf2-1, siNrf2-2 or siNrf2-3), respectively. The protein levels of Nrf2 were evaluated by using Western blot analysis. Data shown represent the mean $\pm \mathrm{SD}(n=3) .{ }^{* * *} p<0.001$ compared with the cells transfected with the control siRNA (siCtrl). siNrf2-1 and siNrf2-2 were selected for subsequent assays according to the efficiency of Nrf2 silencing. (DOCX 7901 kb)

\section{Abbreviations}

B[a]P: benzo(a)pyrene; EdU: 5-Ethynyl-2'-deoxyuridine; ELISA: Enzyme-linked immunosorbent assay; H. cordata: Houttuynia cordata Thunb. (Saururaceae); HO-1: heme oxygenase-1; IL-1 $\beta$ : interleukin-1 $\beta$; MTT: 5-diphenyltetrazolium bromide; NAC: N-Acetyl-L-cysteine; NQO1: NAD(P)H: quinone oxidoreductase 1; Nrf2: nuclear factor E2-related factor-2; P-H2A.X: phosphorylated H2A.X; $\mathrm{ROS}$ : reactive oxygen species; $\mathrm{BH} \mathrm{H}$ : tert-Butylhydroquinone

\section{Acknowledgements}

Not applicable.

\section{Authors' contributions}

All authors contributed to the current study. JW and ZL conceived and designed the experiments; $Y L, Z G, Y Z$ and MK performed the experiments; JW, RZ, FW and LL analyzed the data; JW wrote the paper. All authors read and approved the final manuscript.

\section{Funding}

Acknowledgments: This work was supported by the grants of National Natural Science Foundation of China (81703803, 81720108033 and 81703814), Natural Science Foundation of Guangdong Province (2017A030310464), Department of Education of Guangdong Province 
(2016KQNCX026), and Guangdong Key Laboratory for translational Cancer research of Chinese Medicine (2018B030322011).

\section{Availability of data and materials}

All data generated or analyzed during this study are included in this published article and its additional files.

\section{Ethics approval and consent to participate}

Animal experiments were approved by the Guangzhou University of Chinese Medicine Animal Care and Use Committee (Guangzhou, China), and conducted in accordance with the ethical standards and national guidelines.

\section{Consent for publication}

Not applicable.

\section{Competing interests}

The authors declare that they have no competing interests.

\section{Author details}

${ }^{1}$ Joint Laboratory for Translational Cancer Research of Chinese Medicine of the Ministry of Education of the People's Republic of China, International Institute for Translational Chinese Medicine, Guangzhou University of Chinese Medicine, Guangzhou 510006, Guangdong, China. ${ }^{2}$ State Key Laboratory of Quality Research in Chinese Medicine, Macau University of Science and Technology, Macau, SAR, China. ${ }^{3}$ Hunan Zhengqing Pharmaceutical Group Limited, Huaihua 418005, China.

\section{Received: 19 April 2019 Accepted: 30 May 2019}

\section{Published online: 07 June 2019}

\section{References}

1. Siegel RL, Miller KD, Jemal A. Cancer statistics. Cancer statistics, 2018. 2018; 68(1):7-30.

2. Nanavaty P, Alvarez MS, Alberts WM. Lung cancer screening: advantages, controversies, and applications. Cancer control. 2014;21(1):9-14.

3. Mok TS, Zhou Q, Wu YL. Research and standard care: lung cancer in China. Am Soc Clin Oncol Educ Book. 2012:432-6.

4. Anand P, Kunnumakkara AB, Sundaram C, Harikumar KB, Tharakan ST, Lai OS, et al. Cancer is a preventable disease that requires major lifestyle changes. Pharm Res. 2008;25(9):2097-116.

5. He S, Ou R, Wang W, Ji L, Gao H, Zhu Y, et al. Camptosorus sibiricus rupr aqueous extract prevents lung tumorigenesis via dual effects against ROS and DNA damage. J Ethnopharmacol. 2018:220:44-56.

6. Cheng TY, Cramb SM, Baade PD, Youlden DR, Nwogu C, Reid ME. The International Epidemiology of Lung Cancer: Latest Trends, Disparities, and Tumor Characteristics. J Thorac Oncol. 2016;11(10):1653-71.

7. Lee G, Walser TC, Dubinett SM. Chronic inflammation, chronic obstructive pulmonary disease, and lung cancer. Curr Opin Pulm Med. 2009;15(4):303-7.

8. Wester PW, Muller JJ, Slob W, Mohn GR, Dortant PM, Kroese ED. Carcinogenic activity of benzo[a]pyrene in a 2 year oral study in Wistar rats. Food Chem Toxicol. 2012;50(3-4):927-35.

9. Omidian K, Rafiei H, Bandy B. Polyphenol inhibition of benzo[a]pyreneinduced oxidative stress and neoplastic transformation in an in vitro model of carcinogenesis. Food Chem Toxicol. 2017;106(Pt A):165-74.

10. Naveenkumar C, Raghunandhakumar S, Asokkumar S, Devaki T. Baicalein abrogates reactive oxygen species (ROS)-mediated mitochondrial dysfunction during experimental pulmonary carcinogenesis in vivo. Basic Clin Pharmacol Toxicol. 2013;112(4):270-81.

11. Zhu W, Cromie MM, Cai Q, Lv T, Singh K, Gao W. Curcumin and vitamin E protect against adverse effects of benzo[a]pyrene in lung epithelial cells. PloS one. 2014;9(3):e92992.

12. Briede JJ, Godschalk RW, Emans MT, De Kok TM, Van Agen E, Van Maanen J, et al. In vitro and in vivo studies on oxygen free radical and DNA adduct formation in rat lung and liver during benzo[a]pyrene metabolism. Free Radic Res. 2004:38(9):995-1002.

13. Candido J, Hagemann T. Cancer-related inflammation. J Clin Immunol. 2013; 33(Suppl 1):S79-84

14. Valko M, Rhodes CJ, Moncol J, Izakovic M, Mazur M. Free radicals, metals and antioxidants in oxidative stress-induced cancer. Chem Biol Interact. 2006;160(1):1-40.
15. Valavanidis A, Vlachogianni T, Fiotakis K, Loridas S. Pulmonary oxidative stress, inflammation and cancer: respirable particulate matter, fibrous dusts and ozone as major causes of lung carcinogenesis through reactive oxygen species mechanisms. Int J Environ Res Public Health. 2013;10(9):3886-907.

16. Baumgartner KB, Samet JM, Stidley CA, Colby TV, Waldron JA. Cigarette smoking: a risk factor for idiopathic pulmonary fibrosis. Am J Respir Crit Care Med. 1997;155(1):242-8

17. Jahangir T, Sultana S. Benzo(a)pyrene-induced genotoxicity: attenuation by farnesol in a mouse model. J Enzyme Inhib Med Chem. 2008;23(6):888-94.

18. Young RP, Hopkins RJ, Christmas T, Black PN, Metcalf P, Gamble GD. COPD prevalence is increased in lung cancer, independent of age, sex and smoking history. Eur Respir J. 2009;34(2):380-6.

19. Ohnishi S, Ma N, Thanan R, Pinlaor S, Hammam O, Murata M, et al. DNA damage in inflammation-related carcinogenesis and cancer stem cells. Oxid Med Cell Longev. 2013;2013:387014.

20. Ohshima $H$, Tatemichi M, Sawa T. Chemical basis of inflammation-induced carcinogenesis. Arch Biochem Biophys. 2003:417(1):3-11.

21. Slocum SL, Kensler TW. Nrf2: control of sensitivity to carcinogens. Arch Toxicol. 2011:85(4):273-84

22. Dong Q, Hou H, Wu J, Chen Y. The Nrf2-ARE pathway is associated with Schisandrin b attenuating benzo(a)pyrene-Induced HTR cells damages in vitro. Environ Toxicol. 2016;31(11):1439-49.

23. Thimmulappa RK, Rangasamy T, Alam J, Biswal S. Dibenzoylmethane activates Nif2-dependent detoxification pathway and inhibits benzo(a)pyrene induced DNA adducts in lungs. Med Chem. 2008;4(5):473-81.

24. Banerjee B, Chakraborty S, Ghosh D, Raha S, Sen PC, Jana K. Benzo(a)pyrene Induced p53 Mediated Male Germ Cell Apoptosis: Synergistic Protective Effects of Curcumin and Resveratrol. Front Pharmacol. 2016;7:245.

25. Cao P, Vadhanam MV, Spencer WA, Cai J, Gupta RC. Sustained systemic delivery of green tea polyphenols by polymeric implants significantly diminishes benzo[a]pyrene-induced DNA adducts. Chem Res Toxicol. 2011; 24(6):877-86.

26. Kasala ER, Bodduluru LN, Barua CC, Sriram CS, Gogoi R. Benzo(a)pyrene induced lung cancer: Role of dietary phytochemicals in chemoprevention. Pharmacol Rep. 2015;67(5):996-1009.

27. Liu Y, Wu YM, Zhang PY. Protective effects of curcumin and quercetin during benzo(a)pyrene induced lung carcinogenesis in mice. Eur Rev Med Pharmacol Sci. 2015;19(9):1736-43.

28. Shahid A, Ali R, Ali N, Hasan SK, Bernwal P, Afzal SM, et al. Modulatory effects of catechin hydrate against genotoxicity, oxidative stress, inflammation and apoptosis induced by benzo(a)pyrene in mice. Food Chem Toxicol. 2016;92:64-74.

29. Szabo E, Mao JT, Lam S, Reid ME, Keith RL. Chemoprevention of lung cancer: Diagnosis and management of lung cancer, 3rd ed: American College of Chest Physicians evidence-based clinical practice guidelines. Chest. 2013;143(5 Suppl):e40S-60S.

30. Ng LT, Yen FL, Liao CW, Lin CC. Protective effect of Houttuynia cordata extract on bleomycin-induced pulmonary fibrosis in rats. Am J Chin Med. 2007:35(3):465-75

31. Shingnaisui K, Dey T, Manna P, Kalita J. Therapeutic potentials of Houttuynia cordata Thunb. against inflammation and oxidative stress: A review. J Ethnopharmacol. 2018;220:35-43.

32. Toda S. Antioxidative effects of polyphenols in leaves of Houttuynia cordata on protein fragmentation by copper-hydrogen peroxide in vitro. J Med Food. 2005:8(2):266-8

33. Jang SY, Bae JS, Lee YH, Oh KY, Park KH, Bae YS. Caffeic acid and quercitrin purified from Houttuynia cordata inhibit DNA topoisomerase I activity. Nat Prod Res. 2011;25(3):222-31.

34. Park H, Oh MS. Houttuyniae Herba protects rat primary cortical cells from Abeta(25-35)-induced neurotoxicity via regulation of calcium influx and mitochondria-mediated apoptosis. Hum Exp Toxicol. 2012;31(7):698-709.

35. Chen J, Wang W, Shi C, Fang J. A comparative study of sodium houttuyfonate and 2-undecanone for their in vitro and in vivo antiinflammatory activities and stabilities. Int J Mol Sci. 2014;15(12):22978-94.

36. Verma RS, Joshi N, Padalia RC, Singh VR, Goswami P, Kumar A, et al. Chemical Composition and Allelopathic, Antibacterial, Antifungal, and Antiacetylcholinesterase Activity of Fish-mint (Houttuynia cordataThunb.) from India. Chem Biodivers. 2017:14:10

37. Xu YY, Zhang YY, Ou YY, Lu XX, Pan LY, Li H, et al. Houttuyniacordata Thunb. polysaccharides ameliorates lipopolysaccharide-induced acute lung injury in mice. J Ethnopharmacol. 2015;173:81-90. 
38. Chen YF, Yang JS, Chang WS, Tsai SC, Peng SF, Zhou YR. Houttuynia cordata Thunb extract modulates G0/G1 arrest and Fas/CD95-mediated death receptor apoptotic cell death in human lung cancer A549 cells. J Biomed Sci. 2013:20:18.

39. Shimada K, Crother TR, Karlin J, Dagvadorj J, Chiba N, Chen S, et al. Oxidized mitochondrial DNA activates the NLRP3 inflammasome during apoptosis. Immunity. 2012;36(3):401-14.

40. Wu J, Cheng Z, Zhu L, Lu L, Zhang G, Wang Y, et al. Coadministration of Pinellia ternata Can Significantly Reduce Aconitum carmichaelii to Inhibit CYP3A Activity in Rats. Evid Based Complement Alternat Med. 2014;2014: 734867.

41. Rogakou EP, Pilch DR, Orr AH, Ivanova VS, Bonner WM. DNA doublestranded breaks induce histone H2AX phosphorylation on serine 139. J Biol Chem. 1998;273(10):5858-68.

42. Paull TT, Rogakou EP, Yamazaki V, Kirchgessner CU, Gellert M, Bonner WM. A critical role for histone H2AX in recruitment of repair factors to nuclear foci after DNA damage. Curr Biol. 2000;10(15):886-95.

43. Celeste A, Petersen S, Romanienko PJ, Fernandez-Capetillo O, Chen HT, Sedelnikova OA, et al. Genomic instability in mice lacking histone H2AX. Science. 2002;296(5569):922-7.

44. Yeo CD, Kim YA, Lee HY, Kim JW, Kim SJ, Lee SH, et al. Roflumilast treatment inhibits lung carcinogenesis in benzo(a)pyrene-induced murine lung cancer model. Eur J Pharmacol. 2017;812:189-95.

45. Kastan MB. DNA damage responses: mechanisms and roles in human disease: 2007 G.H.A. Clowes Memorial Award Lecture. Mol Cancer Res. 2008; 6(4):517-24.

46. Ceppi M, Munnia A, Cellai F, Bruzzone M, Peluso MEM. Linking the generation of DNA adducts to lung cancer. Toxicology. 2017;390:160-6.

47. Li L, Zhu T, Gao YF, Zheng W, Wang CJ, Xiao L, et al. Targeting DNA Damage Response in the Radio(Chemo)therapy of Non-Small Cell Lung Cancer. Int J Mol Sci. 2016;17(6)

48. Guo H, Callaway JB, Ting JP. Inflammasomes: mechanism of action, role in disease, and therapeutics. Nat Med. 2015;21(7):677-87.

49. Martin-Sanchez F, Diamond C, Zeitler M, Gomez Al, Baroja-Mazo A, Bagnall J, et al. Inflammasome-dependent IL-1 beta release depends upon membrane permeabilisation. Cell Death Differ. 2016;23(7):1219-31.

50. Zhao R, Zhou H, Su SB. A critical role for interleukin-1 beta in the progression of autoimmune diseases. Int Immunopharmacol. 2013;17(3): 658-69.

51. Castro D, Moreira M, Gouveia AM, Pozza DH, De Mello RA. MicroRNAs in lung cancer. Oncotarget. 2017;8(46):81679-85.

52. Yamamoto Y, Kiyohara C, Suetsugu-Ogata S, Hamada N, Nakanishi Y. Biological interaction of cigarette smoking on the association between genetic polymorphisms involved in inflammation and the risk of lung cancer: A case-control study in Japan. Oncol Lett. 2017;13(5):3873-81.

53. Bhat IA, Naykoo NA, Qasim I, Ganie FA, Yousuf Q, Bhat BA, et al. Association of interleukin 1 beta (IL-1beta) polymorphism with mRNA expression and risk of non small cell lung cancer. Meta gene. 2014;2:123-33.

54. Gomes M, Teixeira AL, Coelho A, Araujo A, Medeiros R. The role of inflammation in lung cancer. Adv Exp Med Biol. 2014;816:1-23.

55. Ridker PM, MacFadyen JG, Thuren T, Everett BM, Libby P, Glynn RJ. Effect of interleukin-1 beta inhibition with canakinumab on incident lung cancer in patients with atherosclerosis: exploratory results from a randomised, double-blind, placebo-controlled trial. Lancet. 2017;390(10105):1833-42.

\section{Publisher's Note}

Springer Nature remains neutral with regard to jurisdictional claims in published maps and institutional affiliations.

Ready to submit your research? Choose BMC and benefit from:

- fast, convenient online submission

- thorough peer review by experienced researchers in your field

- rapid publication on acceptance

- support for research data, including large and complex data types

- gold Open Access which fosters wider collaboration and increased citations

- maximum visibility for your research: over $100 \mathrm{M}$ website views per year

At BMC, research is always in progress.

Learn more biomedcentral.com/submissions 